TITLE:

\title{
Uncertainties in long-period ground motion and its impact on building structural design: Case study of the 2011 Tohoku (Japan) earthquake
}

\section{AUTHOR(S):}

Takewaki, Izuru; Fujita, Kohei; Yoshitomi, Shinta

\section{CITATION:}

Takewaki, Izuru ... [et al]. Uncertainties in long-period ground motion and its impact on building structural design: Case study of the 2011 Tohoku (Japan) earthquake.

Engineering Structures 2013, 49: 119-134

\section{ISSUE DATE:}

2013-04

URL:

http://hdl.handle.net/2433/168513

\section{RIGHT:}

(C) 2012 Elsevier Ltd.; This is not the published version. Please cite only the published version.; この論文は出版社版でありません。引用の際に は出版社版をご確認ご利用ください。 


\title{
Uncertainties of long-period ground motion and its impact on building structural design : Case study of the 2011 Tohoku (Japan) earthquake
}

\author{
Izuru Takewaki $^{*}$, Kohei Fujita and Shinta Yoshitomi ${ }^{+}$ \\ Department of Architecture and Architectural Engineering, Kyoto University, \\ Kyotodaigaku-Katsura, Nishikyo-ku, Kyoto 615-8540, Japan, \\ *Corresponding author: takewaki@archi.kyoto-u.ac.jp \\ + Present address: Ritsumeikan University, Kusatsu 525-8577, Japan
}

\begin{abstract}
On March 11, 2011, Japan was shaken by the 2011 off the Pacific coast of Tohoku earthquake (the Great East Japan Earthquake). This paper reports some aspects of this earthquake and its impact on building structural design. It was reported that long-period ground motions were induced extensively in Tokyo, Nagoya and Osaka. The response of high-rise buildings to the recorded ground motions during this earthquake and the simulated ground motions provided by the Japanese Government is discussed from the viewpoint of resonance and critical excitation. It is shown finally that the earthquake input energy and its bound analysis lead to clearer understanding of the effect of long-period ground motion on building structural design.
\end{abstract}

Keywords: Great East Japan earthquake, long-period ground motion, resonance, critical excitation, earthquake input energy, passively controlled structure

\section{Introduction}

The most devastating earthquake in Japan after the 1923 Great Kanto earthquake occurred on March 11, 2011 [1-3]. The moment magnitude was 9.0 and this is the largest so far in Japan. The earthquake resulted from the thrust faulting near the subduction zone plate boundary between the Pacific and North America Plates [1-3]. Nearly 20,000 people were killed or are still missing by that earthquake and the subsequent monster tsunami as of November 1, 2011.

Because super high-rise buildings in mega cities in Japan had never been shaken intensively by the so-called long-period ground motions before March 11, 2011, the response of high-rise buildings to such long-period ground motions is one of the most controversial subjects and issues in the field of earthquake-resistant design in Japan [4]. It is worthy of noting that most of high-rise and super high-rise buildings in Japan have never been designed in careful strategic responses to such issue. The issue of long-period ground motion, even in a limited sense, and its effect on building structural design was initially brought up in Mexico, USA and Japan during 1980-1990s (for example [5-8]).

This paper discusses the response of assumed super high-rise buildings (40 and 60-story) in Tokyo during this earthquake through the comparison with the reported fact. This is because most of 
the building vibration records and structural design data in actual buildings are not open for public in Japan except limited data, e.g. the top-story displacement, the fundamental natural period of the building. The issue of long-period ground motion and its impact on building structural design are also discussed by using the simulated long-period ground motions provided by the Japanese Government (the Ministry of Land, Infrastructure, Transport and Tourism (MLIT)) [4]. Two 40-story assumed steel buildings are subjected to these simulated long-period ground motions. It is further demonstrated that the high-hardness rubber dampers with high damping capacity [9] are extremely effective for the reduction of response level and duration.

The criticality and uncertainty of the long-period ground motions are then investigated based on the theory of critical excitation [10-13]. The credible bounds (not a small level of probability of occurrence) of input energy responses are obtained by using the robust critical excitation method with the constraints on acceleration and velocity powers. It is shown that the long-period ground motions with a large power in a long-period range are controlled primarily by the velocity power and the ground motions recorded in Tokyo and Osaka during the 2011 off the Pacific coast of Tohoku earthquake actually included long-period wave components. The time-variant property of input energy and the effect of damping level are also discussed in detail. Finally the mechanism of increase of credible bound of input energy is disclosed for the velocity power constraint due to uncertainties in input excitation duration (lengthening) and in structural damping ratio (decrease).

\section{Response simulation of super high-rise buildings}

Fig.1 shows the acceleration and velocity waveforms of the long-period ground motion recorded at K-NET, Shinjuku station (TKY007) [14, 15]. It can be observed that the maximum ground velocity attains about $0.25(\mathrm{~m} / \mathrm{s})$ and the ground shaking continues for more than several minutes. The corresponding velocity response spectra are shown in Fig.2. For the NS component, the velocity response spectra for several damping ratios are plotted. The corresponding ones of the Japanese seismic design code for 5\% damping are also plotted in Fig.2. It should be noted that the ground motions of level 1 are different for low-rise buildings (lower than 60m) and high-rise buildings (higher than $60 \mathrm{~m}$ ). It is understood that these ground motions correspond approximately to the level 1 for high-rise buildings and include long-period components up to 10 seconds $[15,16]$.
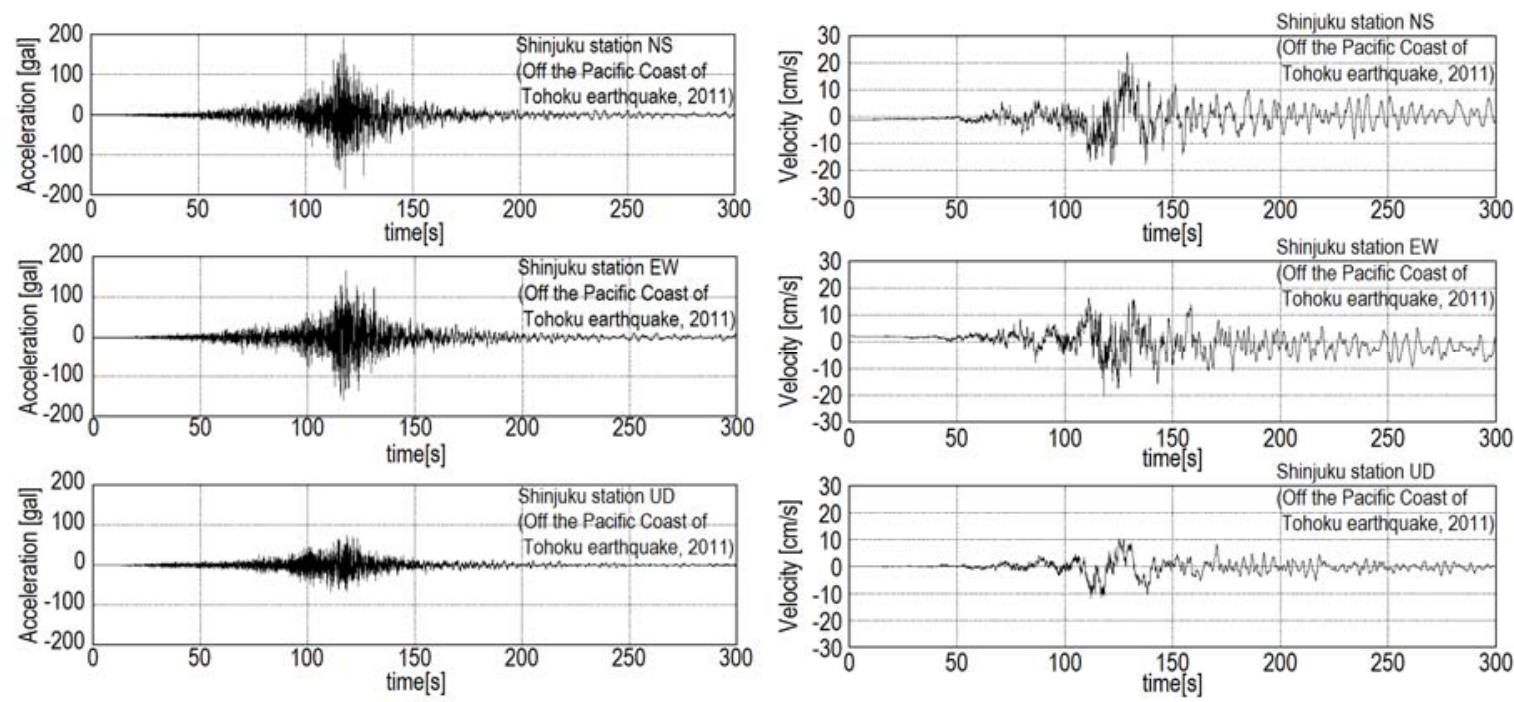

Fig.1 Long-period ground motion at K-NET, Shinjuku station (TKY007) [14] 

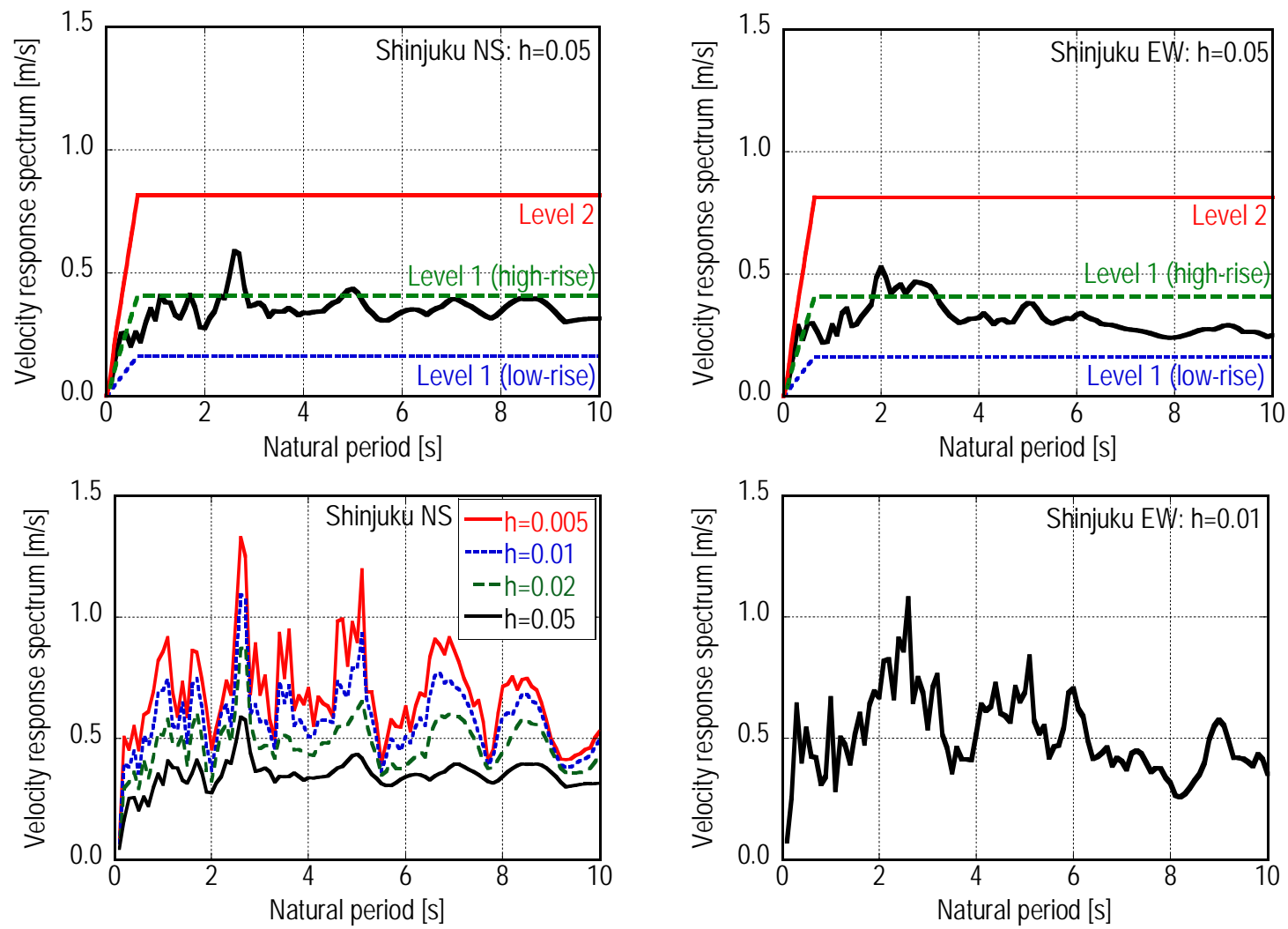

Fig.2 Velocity response spectra of ground motions at K-NET, Shinjuku station (TKY007) and the corresponding level of Japanese code [14]

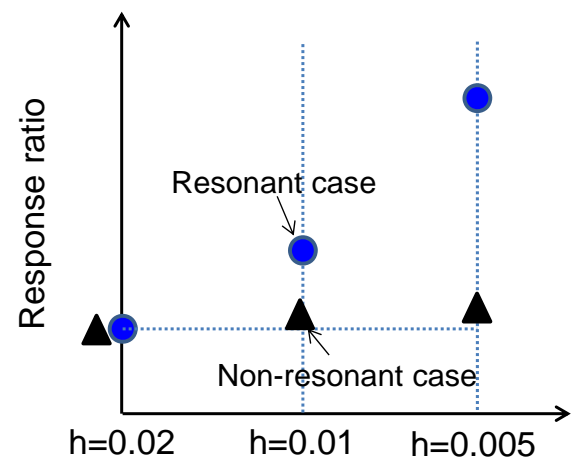

(a)

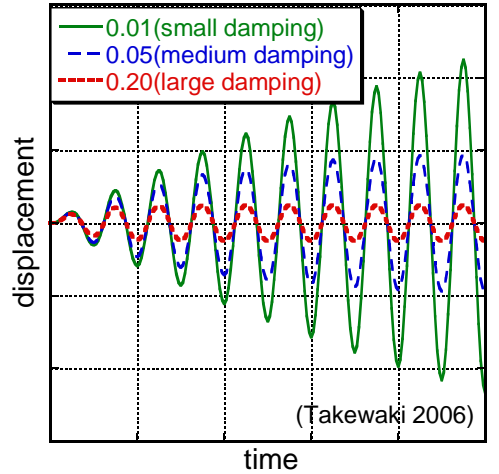

(b)

Fig.3 (a) Response amplification in resonant and random cases, (b) damping effect in resonance

In order to investigate the influence of this ground motion on high-rise buildings, two assumed buildings of 40 and 60 stories have been treated. The buildings have a plan of $40 \mathrm{~m} \times 40 \mathrm{~m}$ (equally spaced 36 columns; span length $=8 \mathrm{~m}$ ) and one planar frame is taken as the object frame. The uniform story height is $4 \mathrm{~m}$. The floor mass per unit area is assumed to be $800 \mathrm{~kg} / \mathrm{m}^{2}$. The damping ratio is taken as 0.01 in accordance with the well-accepted database for high-rise buildings. The detail of member size and its material property are shown in the reference [15]. The 40-story building has the fundamental natural period of $4.14 \mathrm{~s}$ and the 60 -story building has that of 5.92s. Furthermore, it is well accepted that the passive dampers are very effective in the reduction of earthquake response in high-rise buildings. The 2011 off the Pacific coast of Tohoku earthquake may be the first plate-type earthquake to have affected super high-rise buildings in mega cities all over the world. To clarify the 
merit of visco-elastic dampers (high-hardness rubber dampers with high damping capacity [9]), the buildings of 40 and 60 stories without and with these high-hardness rubber dampers have been subjected to the long-period ground motion recorded at K-NET, Shinjuku station (TKY007).

It may be useful to note that the amplification in terms of damping can be expressed approximately by

$1 / h \quad$ for resonant long-period ground motion

$1.5 /(1+10 h)$ for non-resonant conventional ground motion (ratio to $h=0.05)$

It should be noted that Eq.(1a) holds for a sufficiently long duration. This implies the high sensitivity of the response to the damping level in resonant long-period ground motions (Fig.3).

Fig.4 shows the peak story displacements and interstory drifts of two 40-story buildings of $\mathrm{T}_{1}=4.14 \mathrm{~s}$ without and with high-hardness rubber dampers to the EW ground motion at TKY007 in which the frame response is elastic or elastic-plastic. On the other hand, Figs.5(a) and (b) illustrate the peak story displacements and interstory drifts of a 60 -story building of $\mathrm{T}_{1}=5.92 \mathrm{~s}$ to the ground motion at TKY007 in which the frame without or with high-hardness rubber dampers are allowed to behave elastic-plastic. For comparison, the top-story displacement is shown in Fig.5(a) of a 54-story steel building, mentioned in the following paragraph, under almost the same ground motion. The responses with and without dampers correspond fairly well with the simulation results. Fig.5(c) presents the time histories of the top-story displacements of assumed 40-story and 60-story buildings under a ground motion in Chiyoda-ku, Tokyo which has a long duration of 600s. It can be observed that the high-hardness rubber dampers can damp the building vibration effectively both in amplitude and duration. It should be noted that most of KNET motions have a duration limit of 300s for recording purposes which is insufficient for the investigation of the response to long-period ground motions.

It is known $[17,18]$ that a 54 -story steel building (height $=223 \mathrm{~m}$ : fundamental natural period=6.2s (short-span direction), 5.2s (long-span direction)) retrofitted with new-type passive oil dampers including the supporting bracing system in Shinjuku, Tokyo experienced the top displacement of $0.50(\mathrm{~m})$ during the 2011 off the Pacific coast of Tohoku earthquake. The vibration duration was reported to be over 13 minutes. It was also explained that that building would have attained the top displacement of $0.7(\mathrm{~m})$ if the passive dampers would not have been installed. This fact corresponds well to the simulation result explained above (see Fig.5(a)). Figs.6(a), (b) show the ground-level velocity and top-story displacement of that building. It can be observed that, while a rather large vibration of several cycles can be observed during an intensive ground velocity, the amplification is not so large. That may result from the fact that Shinjuku is located on a hard ground and this building had been retrofitted with passive oil dampers.

There is another observation that a 55-story super high-rise building in Osaka (height $=256 \mathrm{~m}$ : $\mathrm{T}_{1}=5.8 \mathrm{~s}$ (long-span direction), $5.3 \mathrm{~s}$ (short-span direction)) was shaken severely regardless of the fact that Osaka is located about $800 \mathrm{~km}$ far from the epicenter (about $600 \mathrm{~km}$ from the boundary of the fault region) and the JMA instrumental intensity was 3 in Osaka [19, 20]. Afterwards the natural periods of the building were found to be longer than the design values reflecting the flexibility of pile-ground systems and the damage to non-structural partition walls etc. It should be pointed out that the level of velocity response spectra of ground motions observed here (first floor) is almost the same as that at the Shinjuku station (K-NET) in Tokyo and the top-story displacement are about 1.4m (short-span direction) and 0.9m (long-span direction). Fig.6(c) shows the ground acceleration, ground velocity and top-story displacement recorded or numerically integrated in this building. It can be observed that a clear resonant phenomenon occurs during about eight cycles (ground fundamental natural period $=4 H / V_{\mathrm{s}}=4 \times 1.6 / 1.0=6.4 \mathrm{~s}$ ). It seems that such clear observation has never been reported in super high-rise buildings all over the world. This implies the need of consideration of long-period ground 
motions in the seismic resistant design of super high-rise buildings in mega cities even though the site is far from the epicenter. It is also being discussed that the expected Tokai, Tonankai and Nankai event is closer to this building (about $160 \mathrm{~km}$ from the boundary of the fault region) and several times of the ground motion may be induced during that event based on the assumption that body waves are predominant outside of the Osaka basin. However the nonlinearity of surface ground and other factors may reduce the amplification. Further investigation will be necessary. The seismic retrofit using hysteretic steel dampers, oil dampers and friction dampers is being planned.
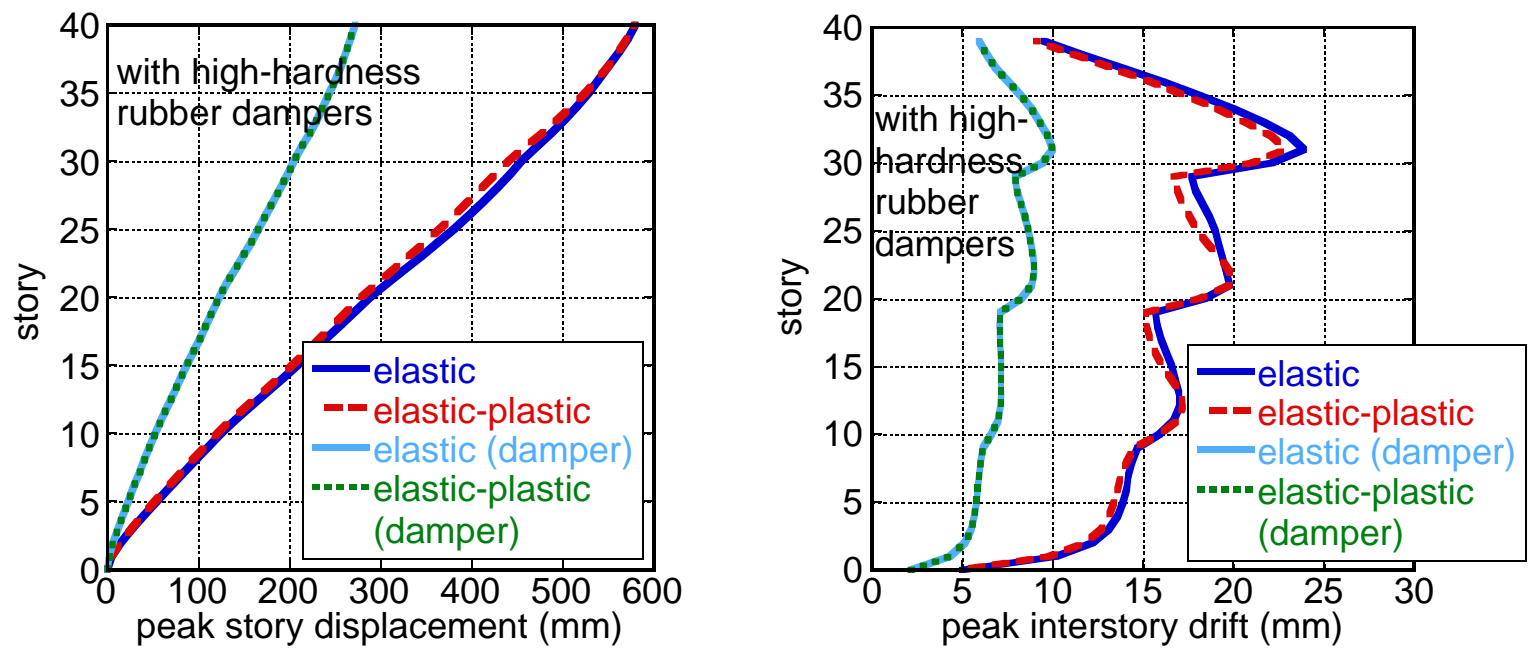

Fig.4 Peak story displacement and interstory drift of an assumed 40-story building of $\mathrm{T}_{1}=4.14 \mathrm{~s}$ without and with high-hardness rubber damper to ground motion at K-NET, Shinjuku station (EW: TKY007) (frame response: elastic or elastic-plastic)

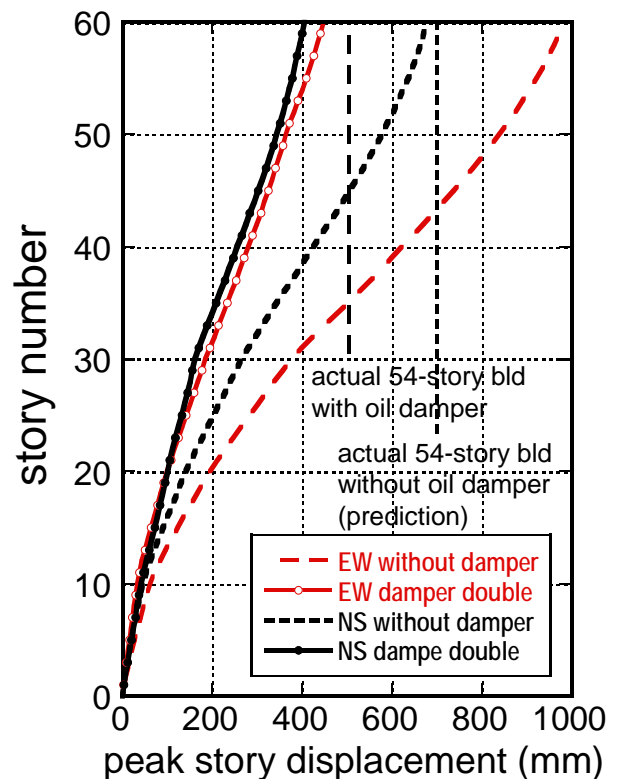

(a)

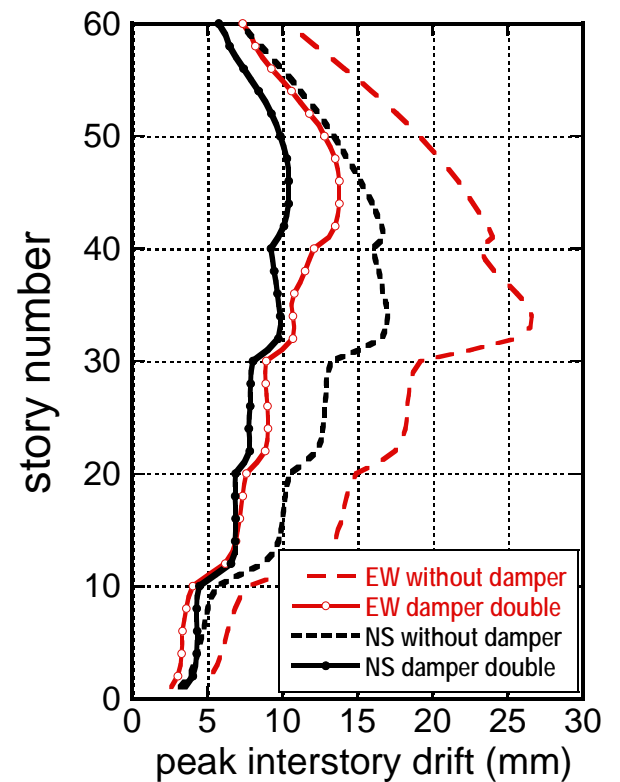

(b)

Fig.5 Peak displacement and interstory drift of an assumed 60-story building of $\mathrm{T}_{1}=5.92 \mathrm{~s}$ to ground motion at K-NET, Shinjuku station (TKY007) (frame response: elastic-plastic, without or with high-hardness rubber dampers) 


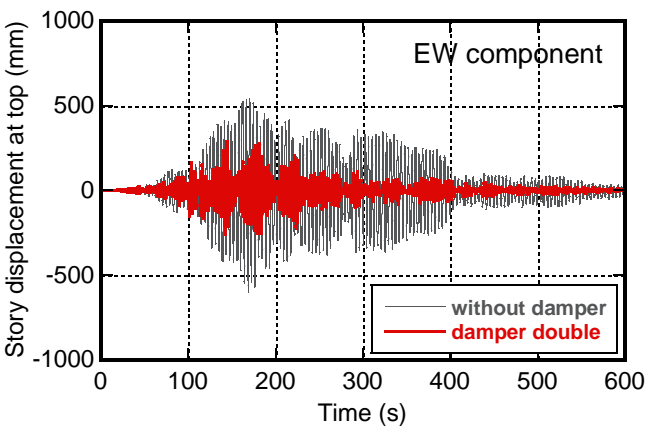

40-story

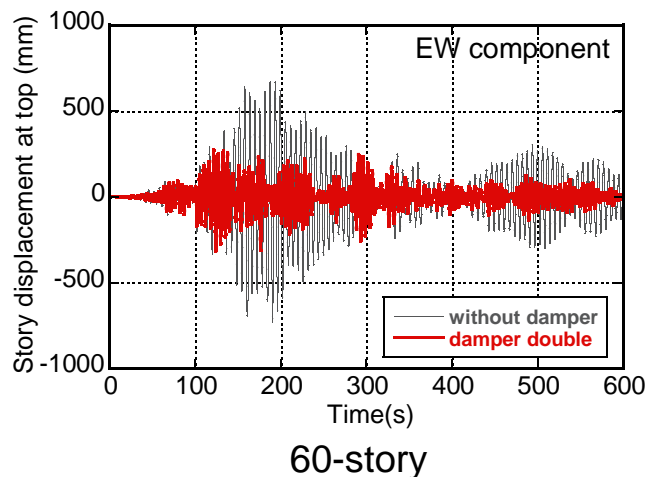

Fig.5(c) Time histories of top-story displacements of assumed 40-story and 60-story buildings under ground motion at Chiyoda-ku

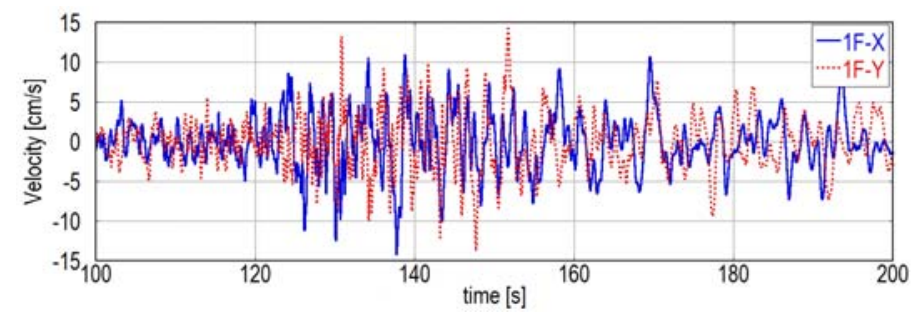

(a) Ground velocity

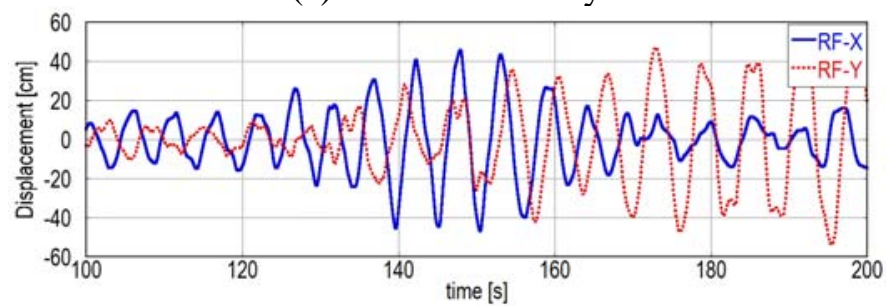

(b) Story displacement at RF

Fig.6 (a) Ground velocity, (b) Top-story displacement of a 54-story building retrofitted with oil dampers in Shinjuku, Tokyo
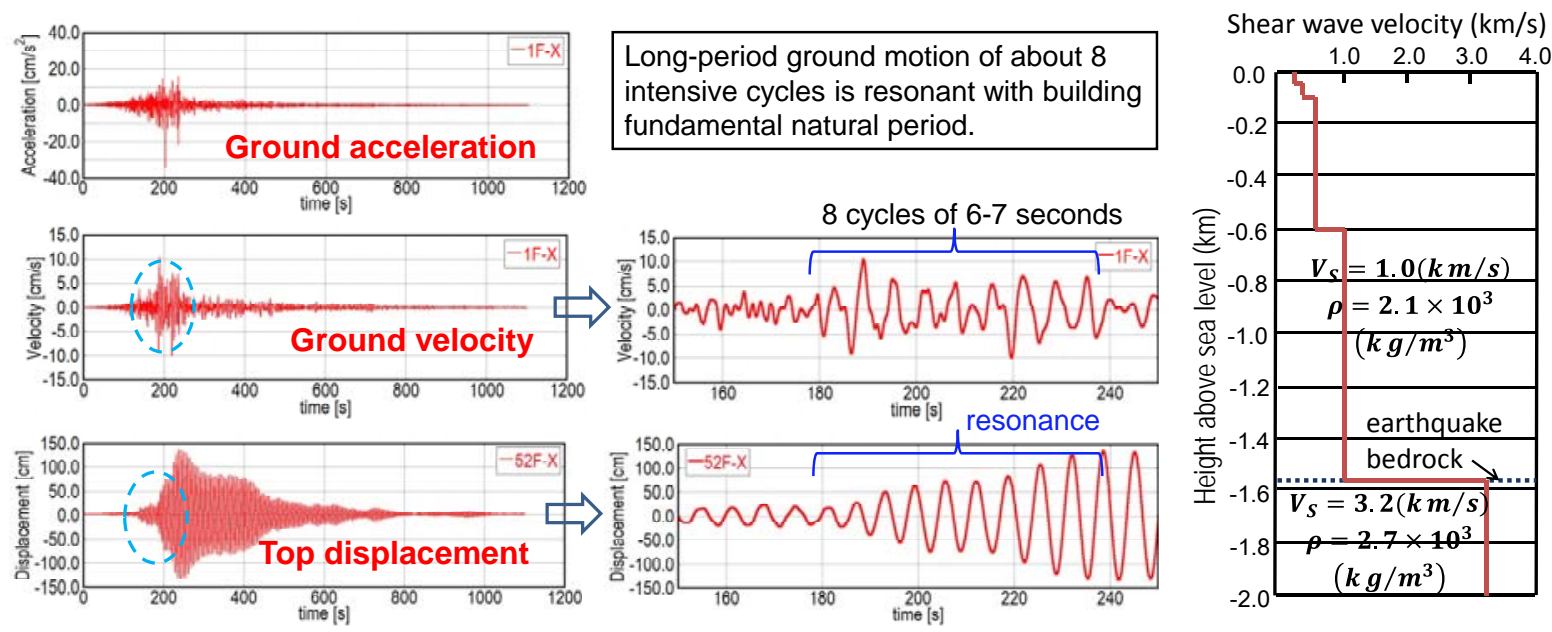

Fig.6(c) Ground acceleration, velocity and top-story displacement of a 55-story building in Osaka 


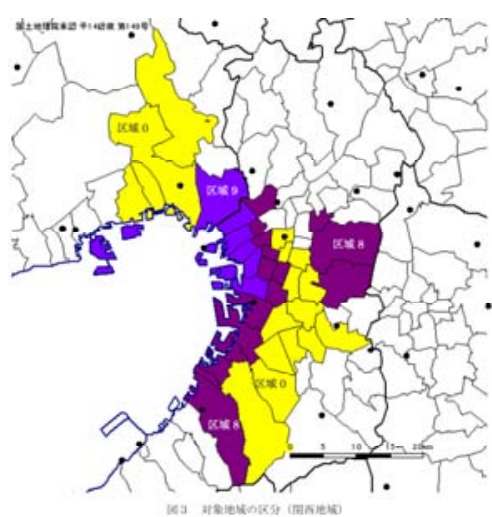

Osaka

(Area 8, 9)

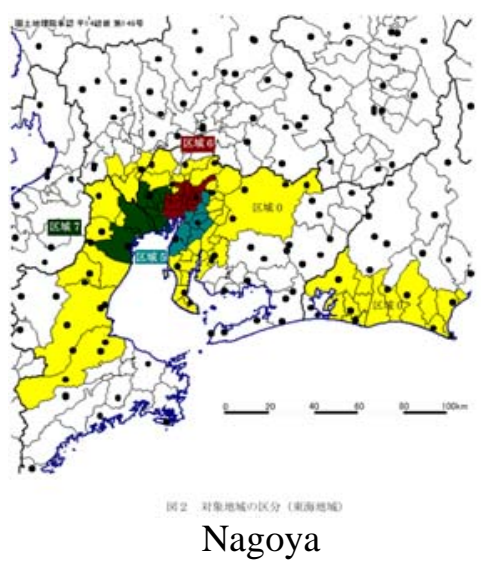

(Area 5-7)

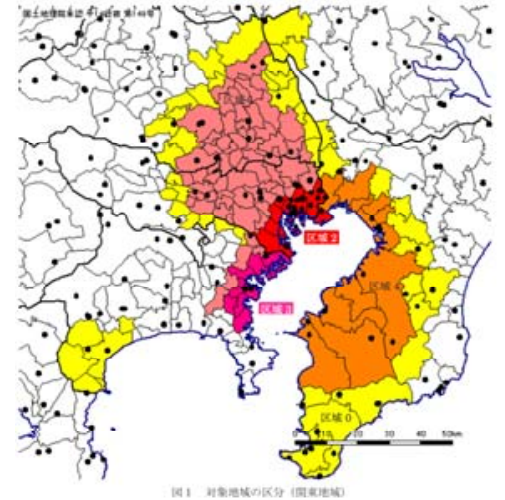

Tokyo

(Area 1-4)

Fig.7 Zoning areas in Osaka, Nagoya and Tokyo [4]

\section{Response of high-rise buildings to simulated long-period ground motions}

\subsection{Simulated long-period ground motions}

On December 21, 2010, the Japanese Government made a press release to upgrade the regulation for high-rise buildings under long-period ground motions. The Ministry of Land, Infrastructure, Transport and Tourism (MLIT) selected and specified 9 areas in Osaka, Nagoya and Tokyo (see Fig.7). Areas 1-4 exist in Tokyo, areas 5-7 in Nagoya and areas 8, 9 in Osaka. MLIT provided simulated long-period ground motions in each area based on the advanced theory of ground motion generation. It was found that large velocity waves appear in later times and the velocity spectra in 2-8 seconds have relatively large magnitudes. It should be remarked that this was conducted before the Tohoku earthquake of March 11, 2011 and a revision of the simulation is under preparation together with the inclusion of the simultaneous occurrence scenario of three great earthquakes predicted in West Japan.

\subsection{Response simulation of high-rise buildings without and with high-hardness rubber dampers}

In order to investigate the influence of the simulated ground motions in areas 1-9 on the response of high-rise buildings, two assumed buildings of 40 stories have been designed. The parameters of the buildings are the same as those stated above. The stiffness of beams has been evaluated as double the original stiffness for the building frame of $\mathrm{T}_{1}=3.6 \mathrm{~s}$ and as 1.5 times the original stiffness for the building frame of $T_{1}=4.14 \mathrm{~s}$. The model of $T_{1}=3.6 \mathrm{~s}$ is a slightly stiff building model and the model of $\mathrm{T}_{1}=4.14 \mathrm{~s}$ is a slightly flexible model. Only the latter one has been treated above. For the purpose of clarifying the merit of visco-elastic dampers (high-hardness rubber dampers [9]), the buildings of 40 stories without and with these high-hardness rubber dampers have been subjected to the simulated long-period ground motions. One damper unit consists of rubber thickness $=15 \mathrm{~mm}$ and rubber area $=0.96 \mathrm{~m}^{2}$. 'Damper single' includes 2 damper units at every story and 'damper double' includes 4 damper units at every story. The model of 'damper double' has been treated above.

Fig.8 illustrates the comparison of the time histories of the top displacement of the 40-story buildings of $\mathrm{T}_{1}=3.6 \mathrm{~s}$ without and with high-hardness rubber dampers (damper double, frame response; elastic) under a simulated long-period ground motion in area 5 (Nagoya area). It can be observed that, while the reduction level of response amplitude due to the high-hardness rubber dampers is only 
20-30\%, those high-hardness rubber dampers are able to damp the building vibration in an extremely shorter duration compared to the building without those dampers.

The comparison of the top displacements of the 40-story buildings of $\mathrm{T}_{1}=3.6(\mathrm{~s})$ (elastic or elastic-plastic, without or with dampers) has been made under the simulated long-period ground motion in area 5. It has been observed that the elastic-plastic response of the building frame decreases the response level to some extent. It seems that the avoidance of resonance by plastic deformation contributes that reduction. It has also been seen that the high-hardness rubber dampers can damp the vibration quickly as in the elastic response. It has been confirmed that this quick vibration reduction rate can be achieved also by viscous dampers like oil dampers so long as an appropriate amount of dampers is provided. The P-delta effect of columns has also been investigated. It has been made clear that the P-delta effect has a small influence on the response in this case.

Fig. 9 shows the ground acceleration, ground velocity and top-story displacement of the 40-story buildings of $\mathrm{T}_{1}=3.6(\mathrm{~s})$ in area 5 (elastic). It can be observed that a clear resonant phenomenon occurs during about three cycles and intensive vibration of the building corresponds well to the velocity wave of the ground motion, not the acceleration wave of that. This is a special character of the response of high-rise buildings under long-period ground motions.
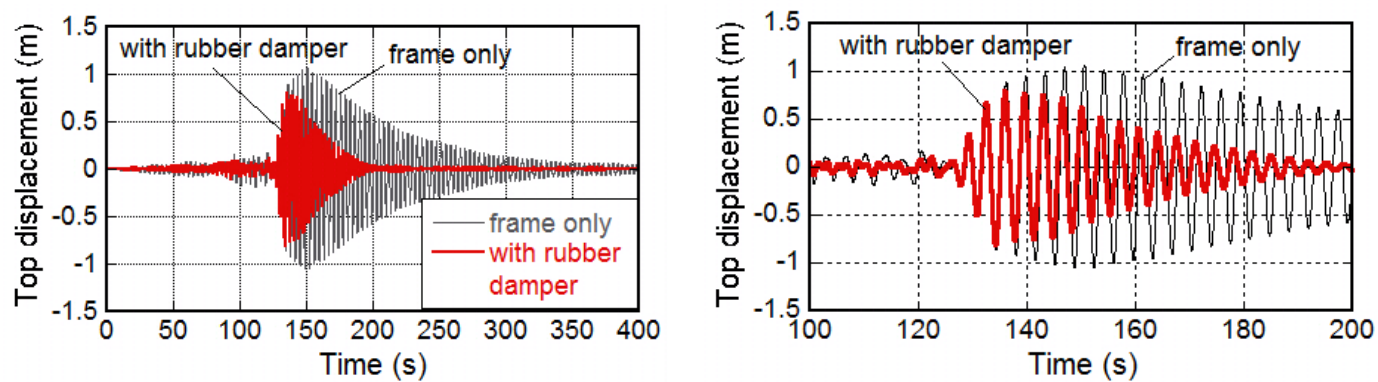

Fig.8 Time histories of top-story displacement of an assumed 40-story building

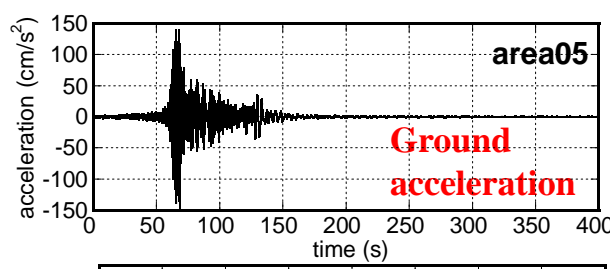

\section{Characteristic of long-period ground motion} almost after the end of ground acceleration.
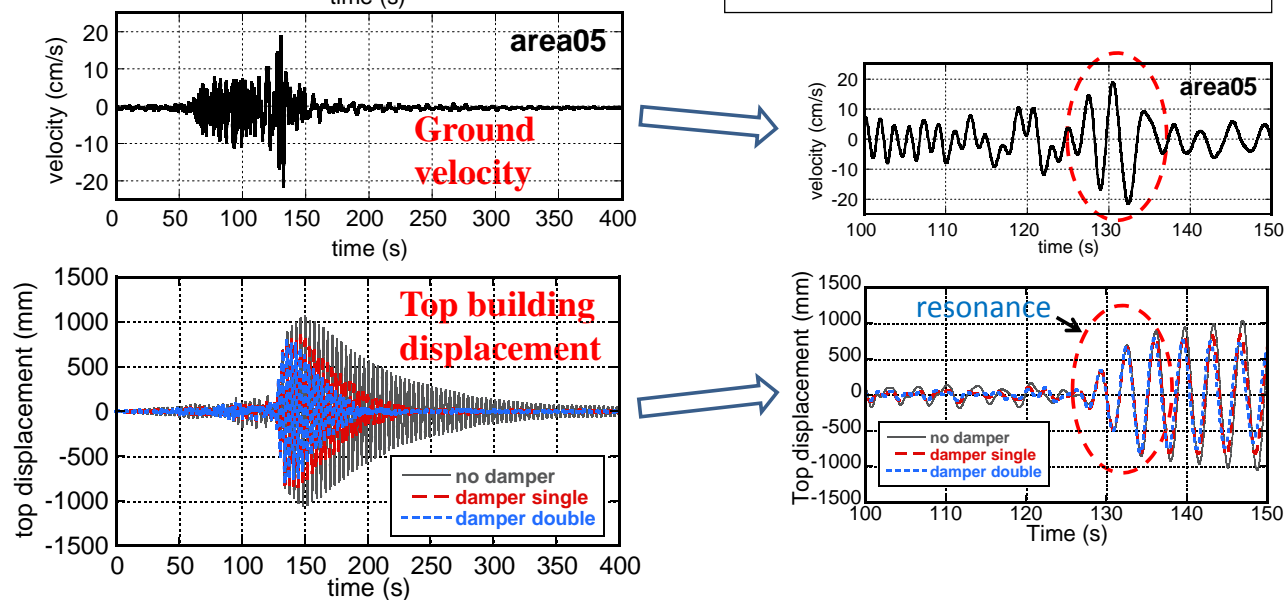

Fig.9 Ground acceleration, velocity and top displacement of an assumed 40-story building in Nagoya 


\section{New paradigm of earthquake resistant design for ground motions including long-period ground motion}

\subsection{Uncertainty in selecting design ground motions}

In order to respond to the issue of long-period ground motions, a new paradigm is desired. There are various buildings in a city. Each building has its own natural period and its original structural properties. When an earthquake occurs, a variety of ground motions are induced in the city. The combination of the building natural period with the predominant period of the induced ground motion may lead to disastrous phenomena in the city (see Fig.10). Many past earthquake observations demonstrated such phenomena repeatedly. Once a devastating earthquake occurs, some building codes are revised and upgraded. However, it may be true that this repetition never resolves all the issues and new serious problems occur. In order to tackle this problem, a new paradigm has to be introduced. The concept of "critical excitation" [10-13] and the structural design based upon this concept can be one of such new paradigms [12].

Earthquake inputs are uncertain both in epistemic and aleatory sense and it does not appear easy to predict forthcoming events precisely [21-23]. Near-field ground motions (Northridge 1994, Kobe 1995, Turkey 1999 and Chi-Chi, Taiwan 1999) and the far-field motions (Mexico 1985, Tohoku 2011) have some peculiar, unpredictable characteristics. It is also true that the civil, mechanical and aerospace engineering structures are often required to be designed for disturbances including inherent uncertainties due mainly to their "low rate of occurrence". It is said in fact that the return period of the earthquake of March 11, 2011 is about 1,000 years. Worst-case analysis combined with proper information based on reliable physical data is expected to play an important role in avoiding difficulties induced by such uncertainties. Approaches based on the concept of "critical excitation" seem to be promising.

The most critical issue in the seismic resistant design is the resonance (see Fig.3). One of the promising approaches to this is to shift the natural period of the building through seismic control [24] and to add damping in the building. However it is also true that the seismic control is under development and more sufficient time is necessary to respond to uncertain ground motions.

It is believed that earthquake has a bound on its magnitude and the earthquake energy radiated from the fault has a bound [25]. The problem is to find the most unfavorable ground motion for a building or a group of buildings (see Fig.10). The Fourier spectrum of a ground motion acceleration has been proposed at the rock surface depending on the seismic moment $M_{0}$, distance $R$ from the fault, etc. (for example [26]).

$$
|A(\omega)|=C M_{0} S\left(\omega, \omega_{C}\right) P\left(\omega, \omega_{\max }\right) \exp \left(-\omega R /\left(2 \beta Q_{\beta}\right) / R\right.
$$

Such spectrum may have uncertainties. One possibility or approach is to specify the acceleration or velocity power [12] as a global measure and allow the variability of the spectrum. As for the Great East Japan Earthquake, $|A(\omega)|$ is reported to be about 0.5(m/s) near the fault region [27]. However this treatment has a difficulty of reliability of the theory and of specification of the fault site. The change of ground motion by surface soil conditions is another difficulty. Based on this observation, a concept of critical excitation is introduced.

A significance of critical excitation is supported by its broad perspective. In general there are two classes of buildings in a city. One is the important building which plays an important role during and after disastrous earthquakes. The other is ordinary building. The former one should not get damaged during an earthquake and the latter one may be damaged partially especially for critical excitation larger than code-specified design earthquakes. Just as the investigation on limit states of 
structures plays an important role in the specification of response limits and performance levels of structures during disturbances, the clarification of critical excitations for a given structure or a group of structures appears to provide structural designers with useful information in determining excitation parameters in a risk-based reasonable way. It is expected that the concept of critical excitation enables structural designers to make ordinary buildings more seismic-resistant and seismic-resilient.

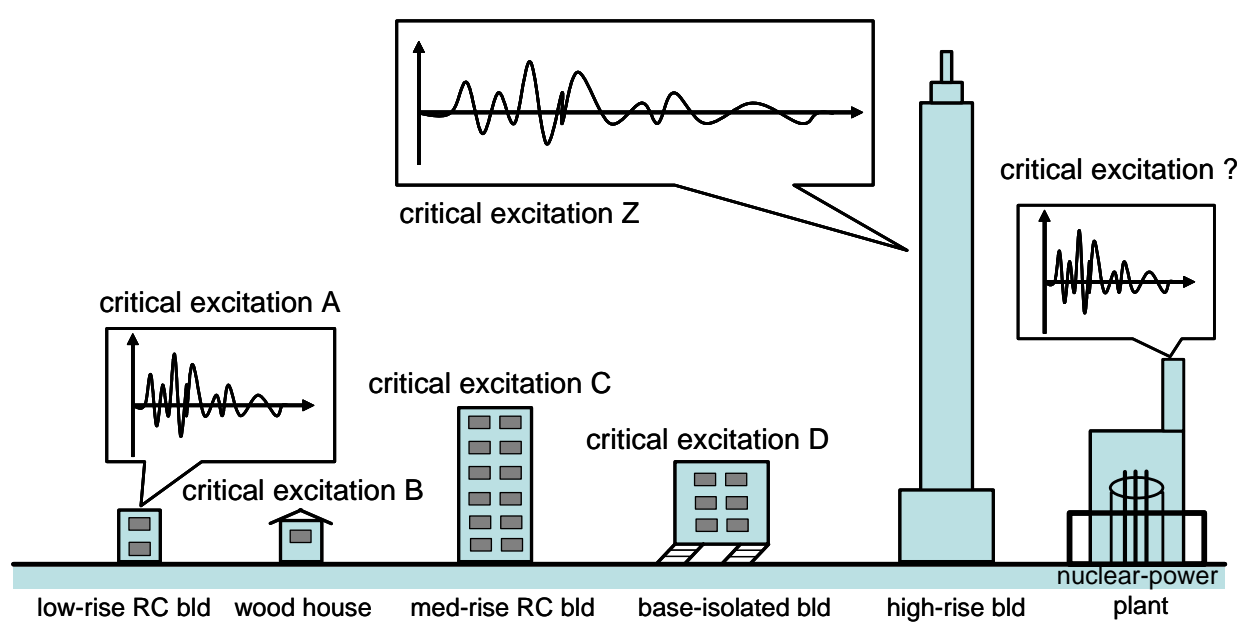

Fig.10 Structure-dependent critical excitation
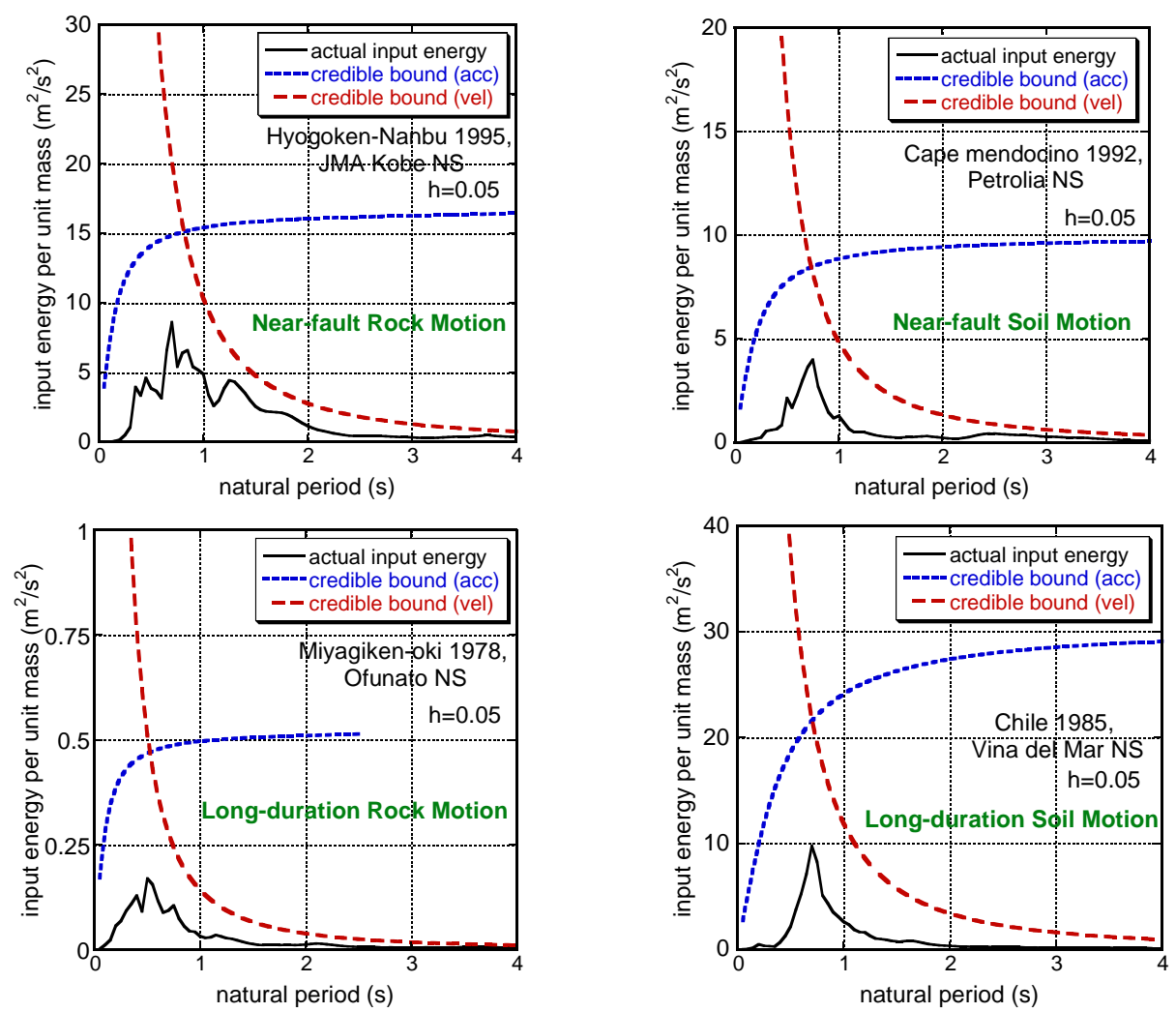

Fig.11 Credible bound of input energy for various types of ground motions (near-fault rock motion, near-fault soil motion, long-duration rock motion, long-duration soil motion) [11] 


\subsection{Representation of uncertainty of long-period ground motion by critical excitation theory for earthquake input energy}

The total input energy is an appropriate quantity for evaluating the demand of earthquake ground motions [11, 28, 29]. It is appropriate from the viewpoint of uncertainties of ground motions and structures to introduce the credible bounds (not a small level of probability of occurrence) of the input energy per unit mass $E_{I} / m$ to a single-degree-of-freedom (SDOF) model for acceleration and velocity constraints. In order to explain the credible bounds of the input energy, let us introduce the energy transfer function $F(\omega)$ defined by

$$
F(\omega)=\frac{2 h \Omega \omega^{2}}{\pi\left\{\left(\Omega^{2}-\omega^{2}\right)^{2}+(2 h \Omega \omega)^{2}\right\}}
$$
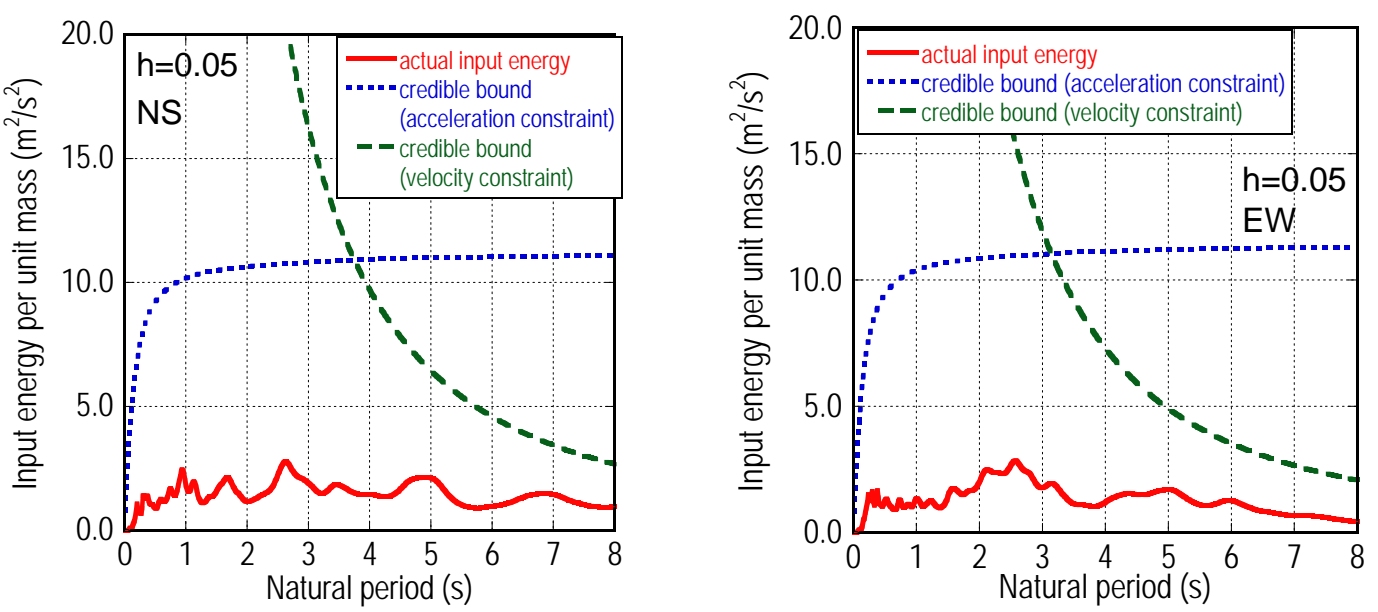

Fig.12 Credible bound of input energy for ground motion recorded at K-NET,

Shinjuku station (TKY007)
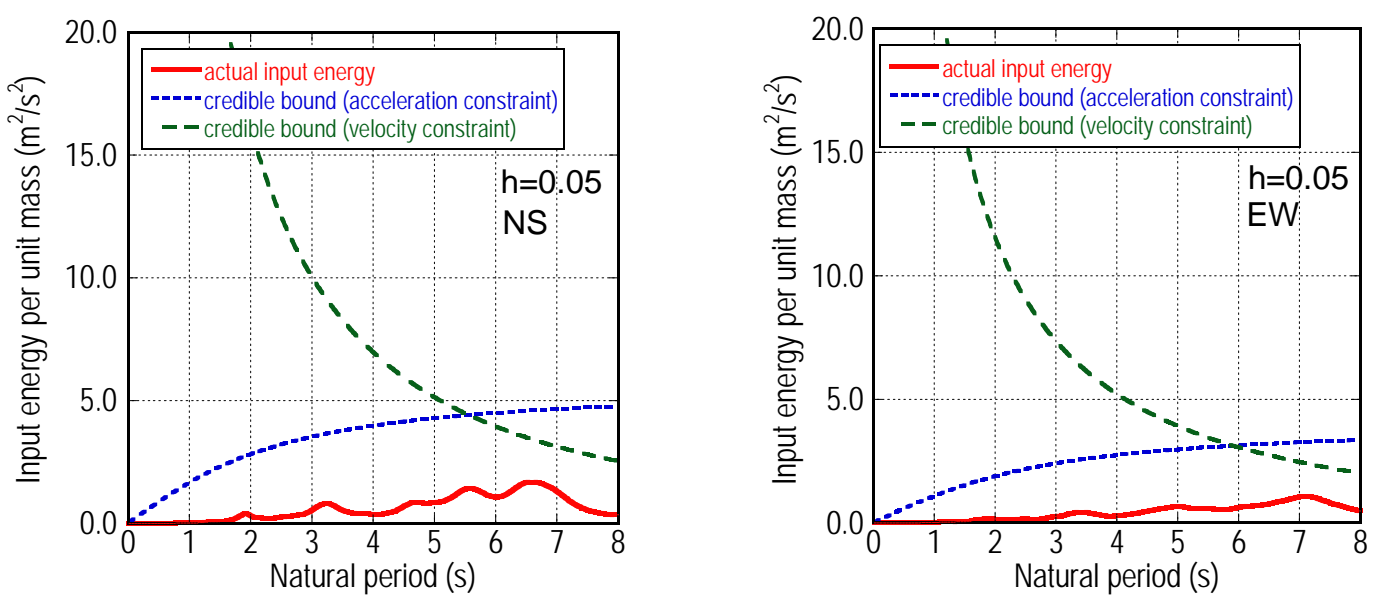

Fig.13 Credible bound of input energy for ground motion recorded in Osaka bay area 
where $\Omega$ : natural circular frequency of the SDOF model, $h$ : damping ratio and $\omega$ : the excitation frequency. This energy transfer function can be derived as $-\operatorname{Re}\left[H_{V}(\omega ; \Omega, h)\right] / \pi$ where $H_{V}(\omega ; \Omega, h)$ is the velocity transfer function defined by $\dot{X}(\omega)=H_{V}(\omega ; \Omega, h) A(\omega) \quad(\dot{X}(\omega)$ : Fourier transform of response velocity of the SDOF model, $A(\omega)$ : Fourier transform of ground acceleration). The input energy per unit mass $E_{I} / m$ to the SDOF model can then be expressed by

$$
E_{I} / m=\int_{0}^{\infty}|A(\omega)|^{2} F(\omega) \mathrm{d} \omega
$$

or

$$
E_{I} / m=\int_{0}^{\infty}|V(\omega)|^{2} \omega^{2} F(\omega) \mathrm{d} \omega
$$

where $V(\omega)$ is the Fourier transform of the ground velocity. The credible bounds of the input energy per unit mass $E_{I} / m$ to a single-degree-of-freedom (SDOF) model for acceleration and velocity constraints can be obtained by modeling the Fourier amplitude of the worst input acceleration and velocity as rectangular ones centered at the natural frequency of the SDOF model $[11,12]$. The maximum value of actual Fourier amplitude of a ground motion is used as the height of the rectangular Fourier amplitude. This point could be discussed in more detail for deeper understanding of 'credible bound'. The introduction of Eq.(2) may be one possibility and an effective strategy for advanced and sophisticated treatment of uncertain ground motions.

Fig.11 presents the credible bounds of input energy for JMA Kobe NS during Hyogoken-Nanbu earthquake 1995, Petrolia NS during Cape Mendocino earthquake 1992, Ofunato NS during Miyagiken-oki earthquake 1978 and Vina del Mar NS during Chile earthquake 1985. It is seen that the property of the uniform risk holds. In other words, the distance from the actual input energy to the credible bound is almost constant in a wide range of natural period. On the other hand, Fig.12 shows those for ground motions recorded at K-NET, Shinjuku station (TKY007) and Fig.13 illustrates those for ground motions recorded in Osaka bay area. It can be found that the ratio of the bound to the corresponding actual input energy is large. This implies that the ground motion of March 11 includes wave components in a broad period range and this contradicts to the procedure of concentrating wave components to one frequency.

\subsection{Analysis of earthquake energy input in Tokyo and Osaka during 2011 Tohoku earthquake}

Fig.14 shows the time variation of input energy $(h=0.05)$ for SDOF system with various natural periods for the ground motion recorded at K-NET Shinjuku station (TKY007). On the other hand, Fig.15 illustrates the increment of input energy in a specified time duration for that ground motion. The time increment for the computation of the increment of input energy was set to 3(s). This is almost the same as the earthquake input rate spectrum [30, 31]. This concept is based on the squared Fourier amplitude spectrum of a ground motion truncated at an arbitrary time $t$ [30, 32, 33]. It can be seen that the energy input from the short-period ground motions inducing a large energy input to short-natural period systems appear first and that from the long-period ground motions inducing a large energy input to long-natural period systems follow. It is also clear that the ground motion recorded at K-NET Shinjuku station (TKY007) includes fairly wide-range frequency components. One of the reasons may result from the fact that Shinjuku is located on a hard ground. For this reason, higher-mode responses are induced and relatively large response accelerations were observed at higher stories. 

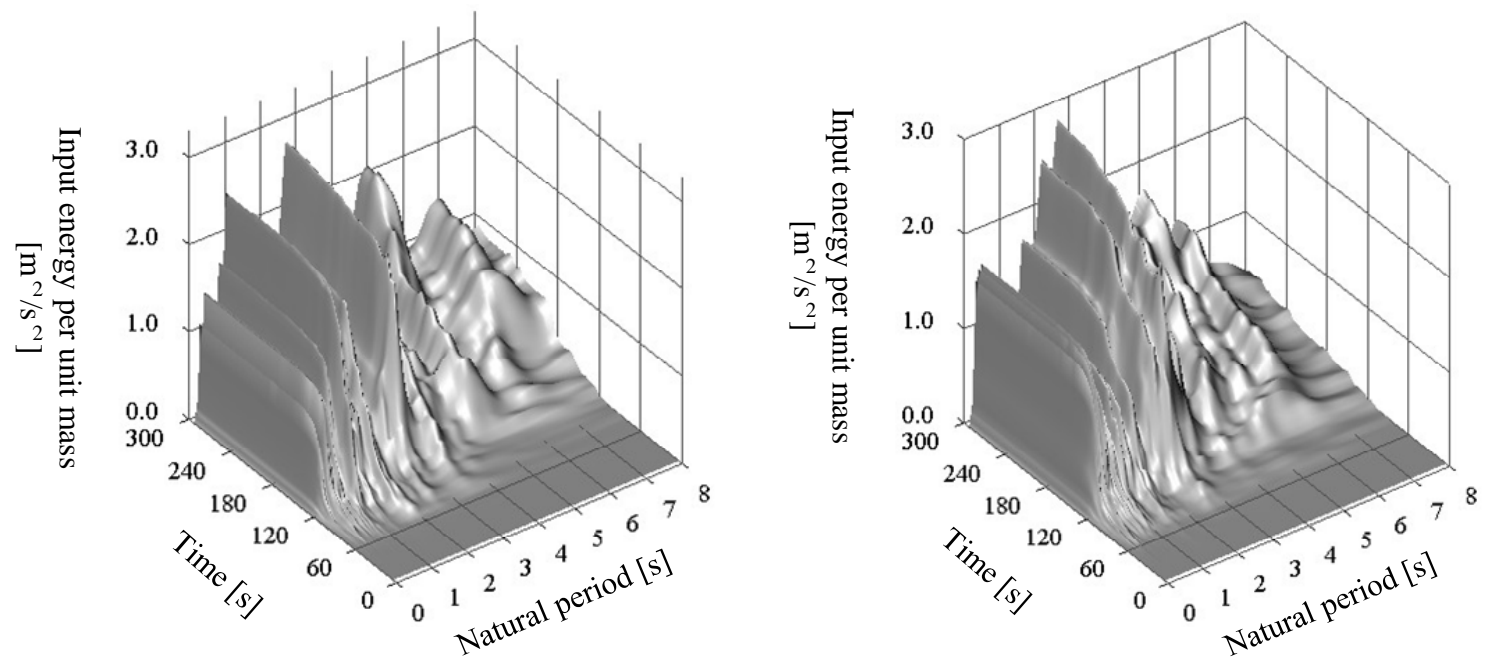

Fig.14 Time variation of input energy from ground motion recorded at K-NET Shinjuku station (TKY007) (h=0.05) (left: NS, right: EW)
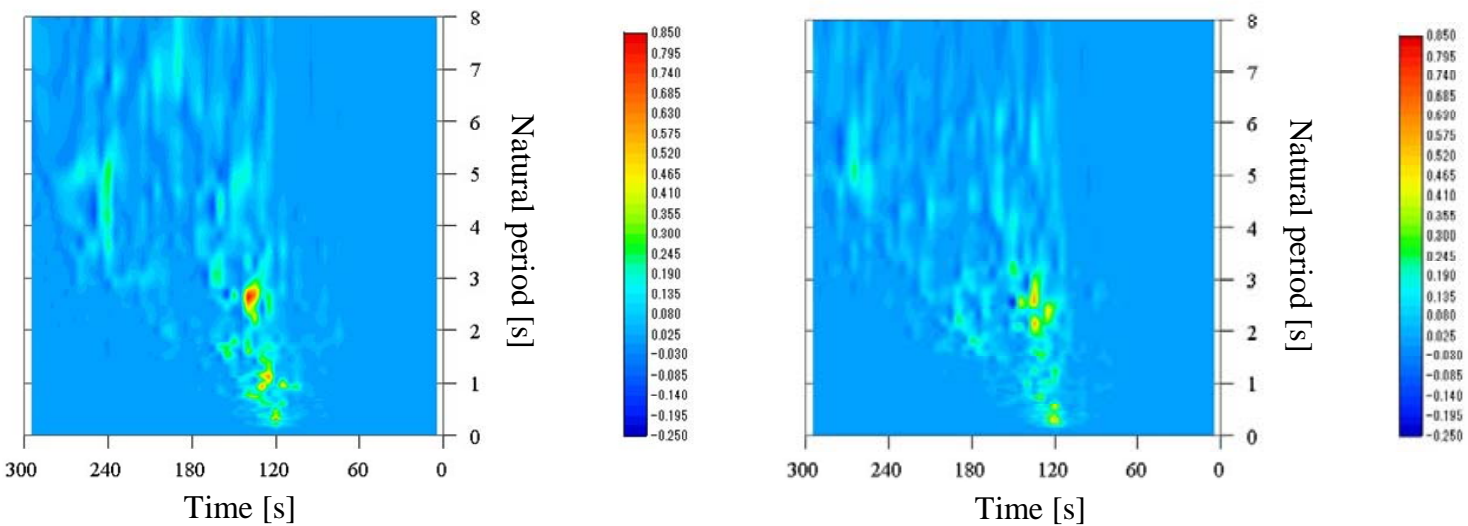

Fig.15 Increment of input energy in a specified time duration from ground motion recorded at K-NET Shinjuku station (TKY007) (h=0.05) (left: NS, right: EW) 

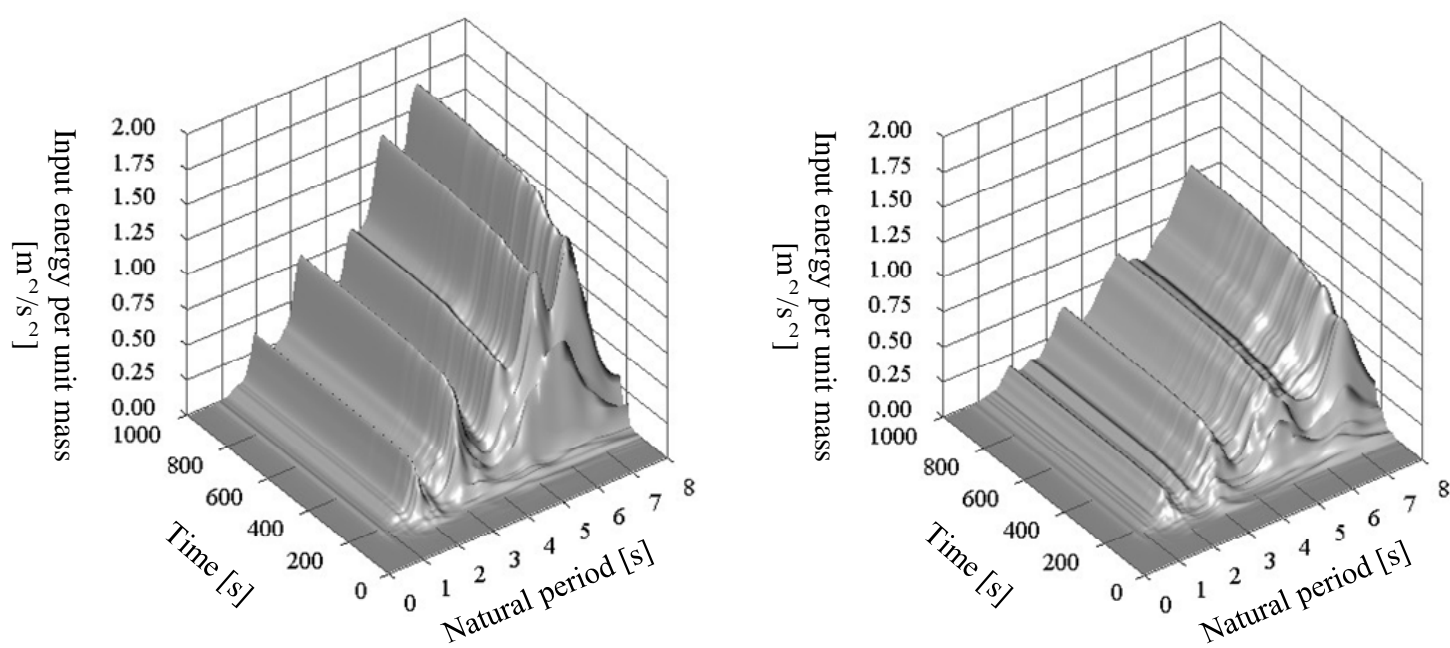

Fig.16 Time variation of input energy from ground motion recorded in Osaka bay area $(\mathrm{h}=0.05)$ (left: NS, right: EW)
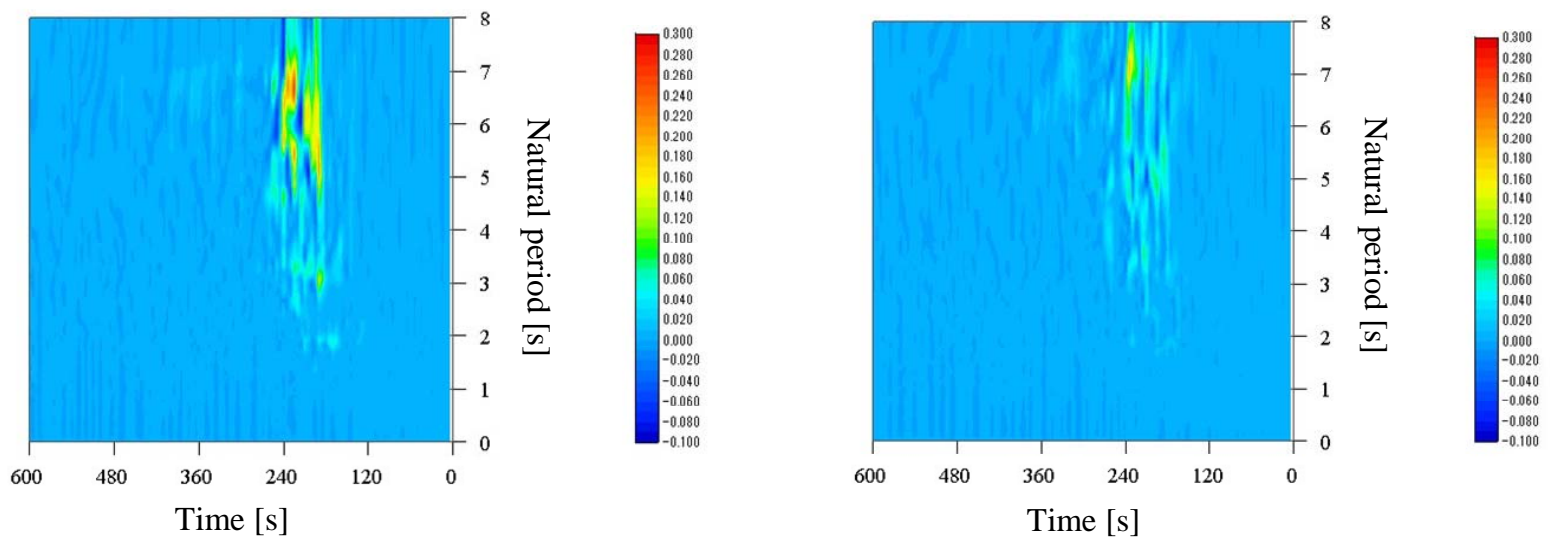

Fig.17 Increment of input energy in a specified time duration from ground motion recorded in Osaka bay area $(\mathrm{h}=0.05)$ (left: NS, right: $\mathrm{EW})$

Fig.16 shows the time variation of input energy $(h=0.05)$ from the ground motion recorded at Osaka bay area. On the other hand, Fig.17 presents the increment of input energy in a specified time duration from the same ground motion. The time increment was set to 5(s). Different from the ground motion at K-NET Shinjuku station (TKY007), the energy input from the long-period ground motions exist from the beginning of shaking. It can be understood that, while Tokyo is located rather close to the fault (about $160 \mathrm{~km}$ ) and an intensive shaking occurred (the JMA instrumental intensity was about 5), Osaka is located far from the fault (about $600 \mathrm{~km}$ ) and an intensive shaking did not occur on the ground (the JMA instrumental intensity was about 3). This implies that, even if an intensive shaking is not observed, an influence may arrive at high-rise buildings depending on the relationship of the natural period of the building and the predominant period of the ground.

Fig.18(a) presents the total earthquake input energy from the ground motion at K-NET Shinjuku station (TKY007, NS) for various damping ratios and Fig.18(b) illustrates the corresponding energy spectrum. It can be seen that, as the damping becomes larger, the energy spectrum becomes smoother. This phenomenon is related to the so-called 'smoothing of Fourier amplitude spectrum' (approximately equivalent to zero-damping velocity response spectrum) [34]. Fig.19 shows the time 
variation of input energy from the ground motion recorded at K-NET Shinjuku station (TKY007, NS) for various damping ratios. The smoothing process with respect to damping level can be seen clearly.

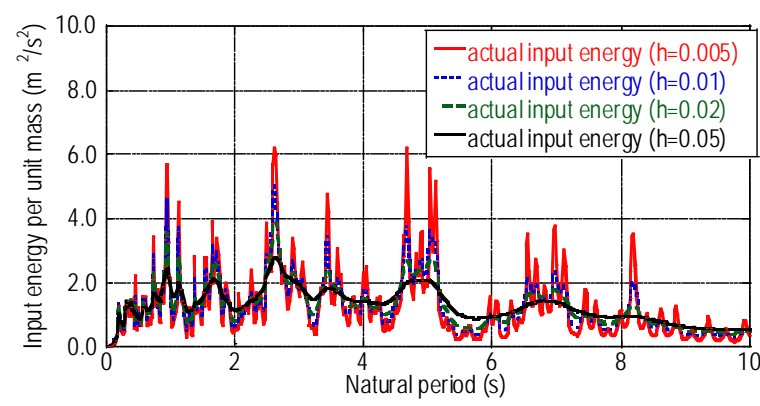

(a) Total earthquake input energy

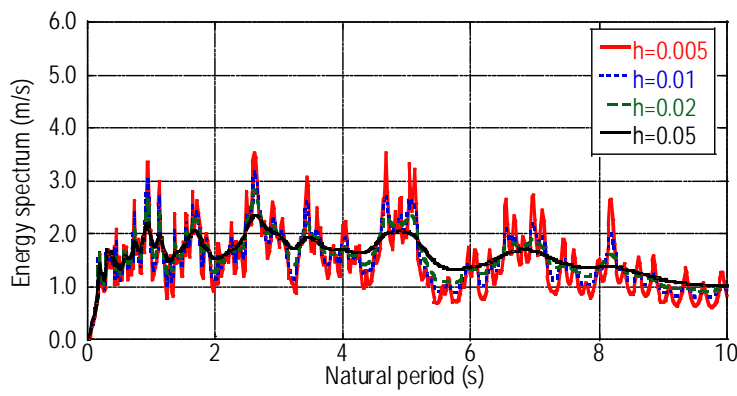

(b) Energy spectrum

Fig.18 Total earthquake input energy from ground motion at K-NET Shinjuku (TKY007, NS) for various damping ratios and energy spectrum

(a)

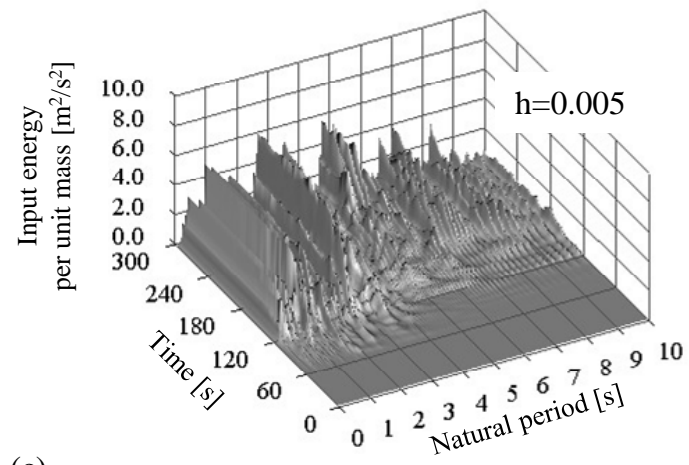

(c)

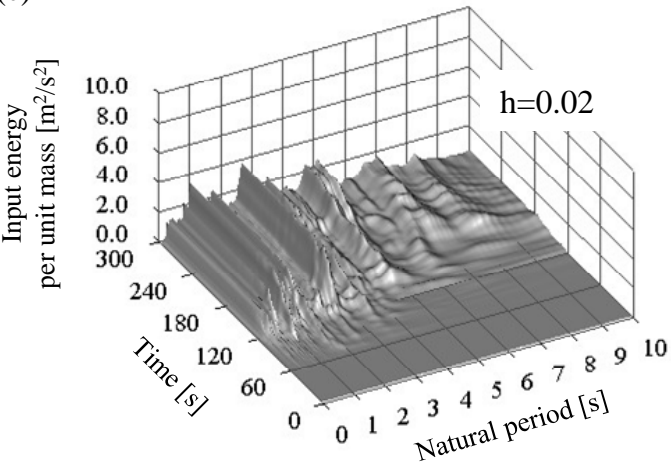

(b)

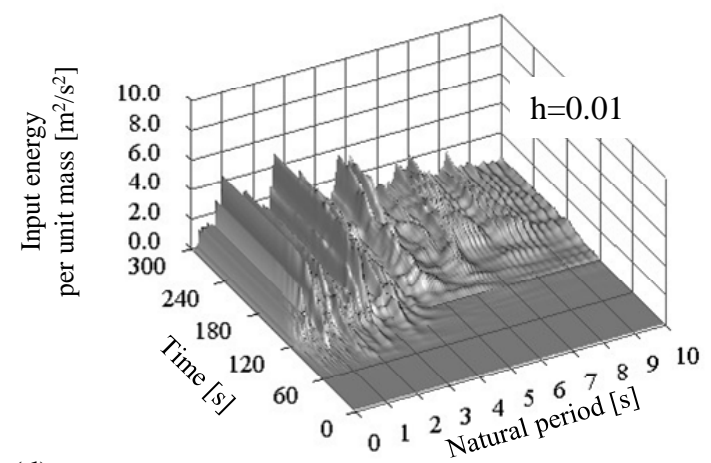

(d)

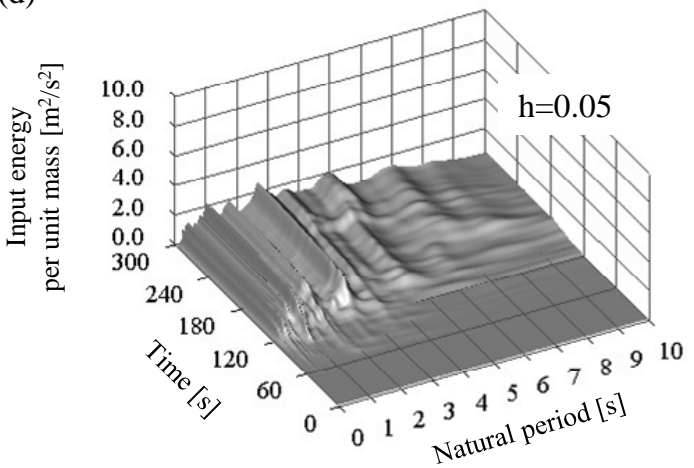

Fig.19 Time variation of input energy from ground motion at K-NET Shinjuku (TKY007, NS) for various damping ratios 
Fig.20 illustrates the total input energy from the ground motion at Osaka bay area (NS) for various damping ratios together with the corresponding energy spectrum. On the other hand, Fig.21 shows the time variation of input energy from the same ground motion for various damping ratios. The smoothing process with respect to damping level can be seen also in this ground motion and it is clear that a large energy input can be observed around 5.5-7.0s. This can be explained by the fact that this building has fundamental natural periods of 6.5-7.0s in both directions and the surface ground fundamental natural period is about $6.5 \mathrm{~s}$.

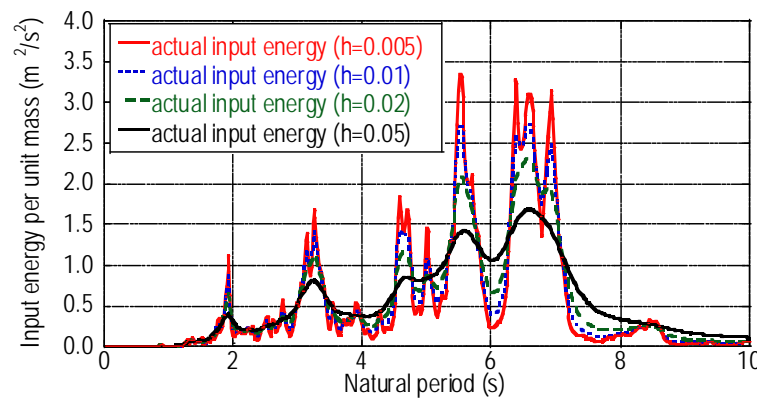

(a) Total earthquake input energy

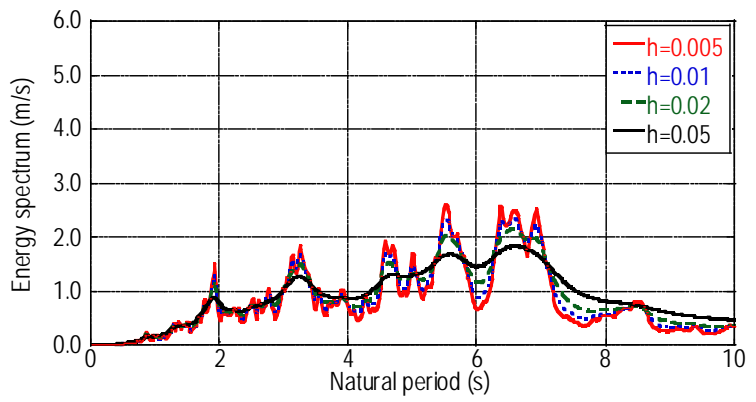

(b) Energy spectrum

Fig.20 Total earthquake input energy from ground motion at Osaka bay area (NS) for various damping ratios and energy spectrum

(a)

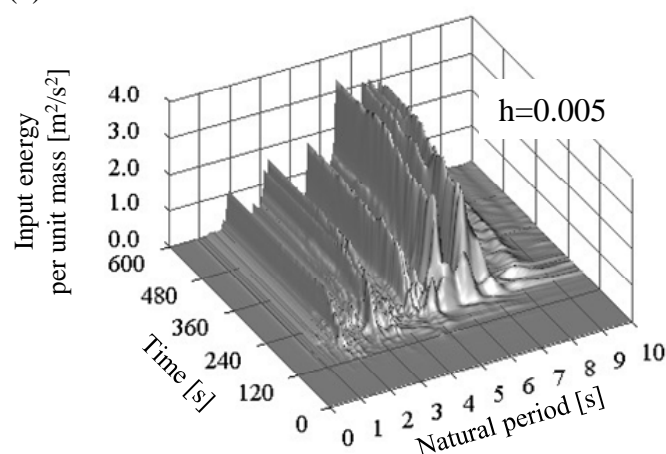

(c)

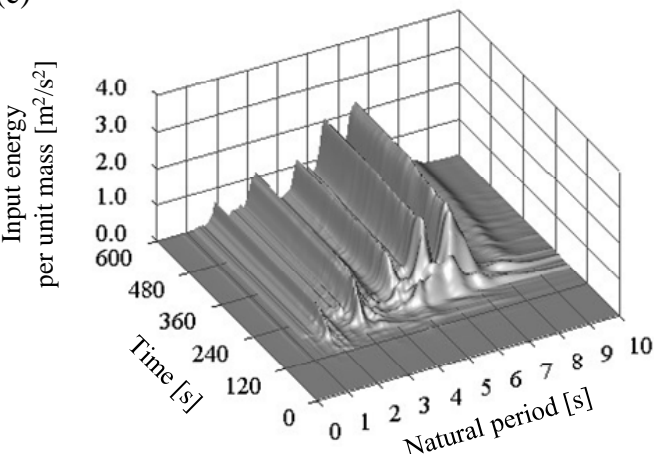

(b)

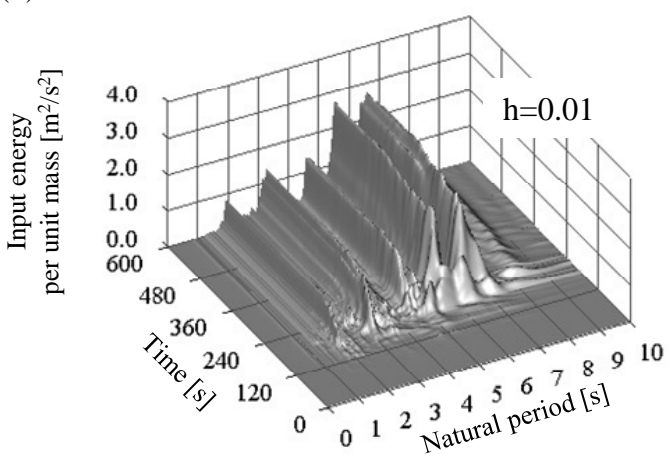

(d)

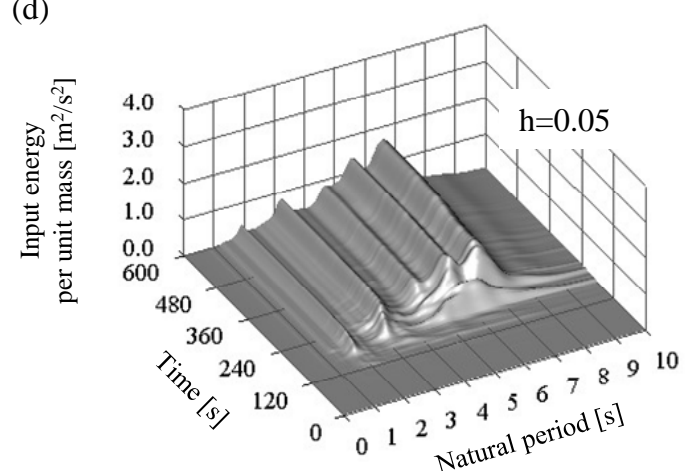

Fig.21 Time variation of input energy from ground motion at Osaka bay area (NS) for various damping ratios 
In order to clarify the difference of earthquake input mechanism between the long-period ground motions and the near-field ground motions, the ground motion at JMA Kobe (NS) during Hyogoken-Nanbu earthquake 1995 has been treated. Fig.22 presents the total input energy from the ground motion at JMA Kobe (NS) during Hyogoken-Nanbu earthquake 1995 for various damping ratios together with the corresponding energy spectrum. On the other hand, Fig.23 shows the time variation of input energy from the same ground motion for various damping ratios. It can be seen that, different from the long-period ground motions, most energy is concentrated to the short period range around 1(s) and the variability of input energy due to change of damping is not remarkable in the long-period range.

It should be remarked that the computation of earthquake input energy in frequency domain enhances the numerical efficiency for various damping ratios.

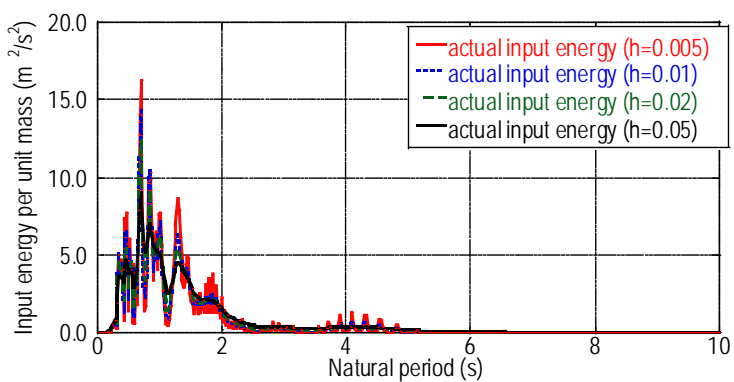

(a) Total earthquake input energy

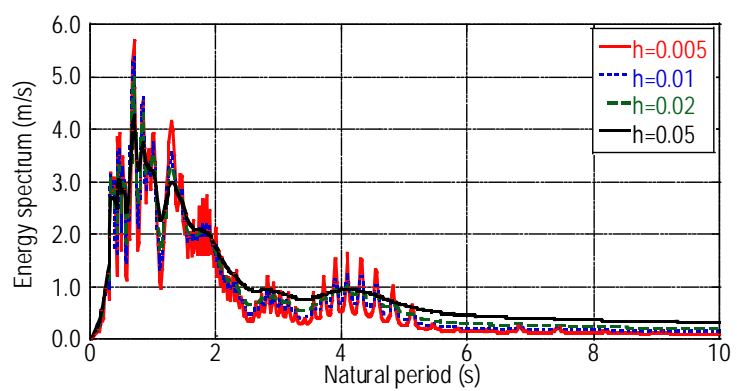

(b) Energy spectrum

Fig.22 Total earthquake input energy from ground motion at JMA Kobe (NS) during Hyogoken-Nanbu earthquake 1995 for various damping ratios and energy spectrum

(a)

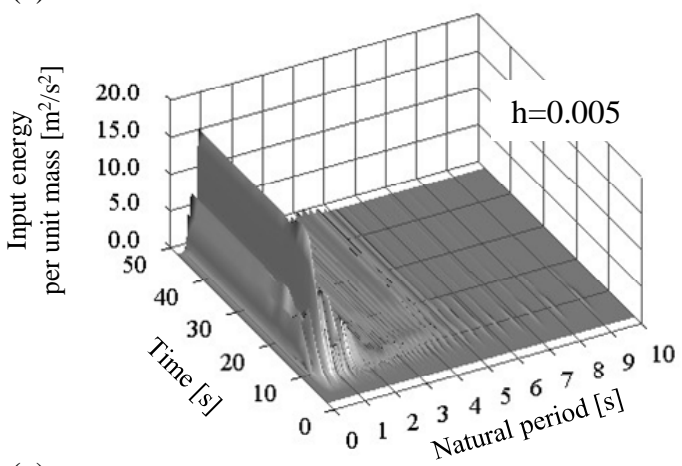

(c)

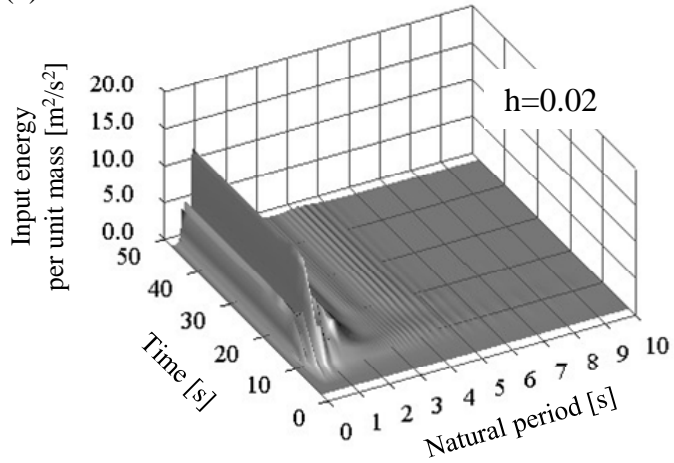

(b)

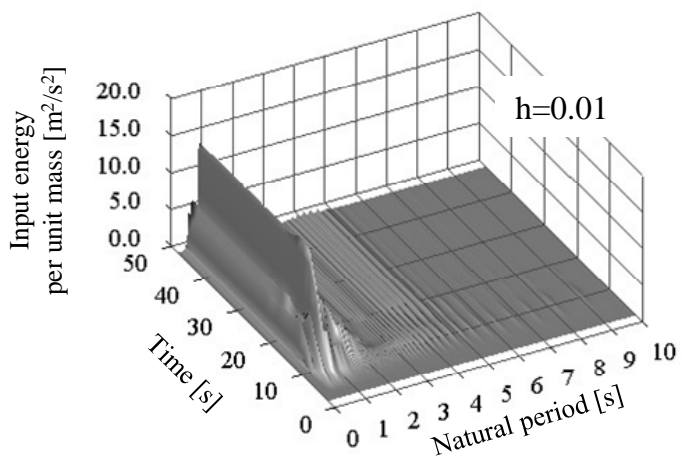

(d)

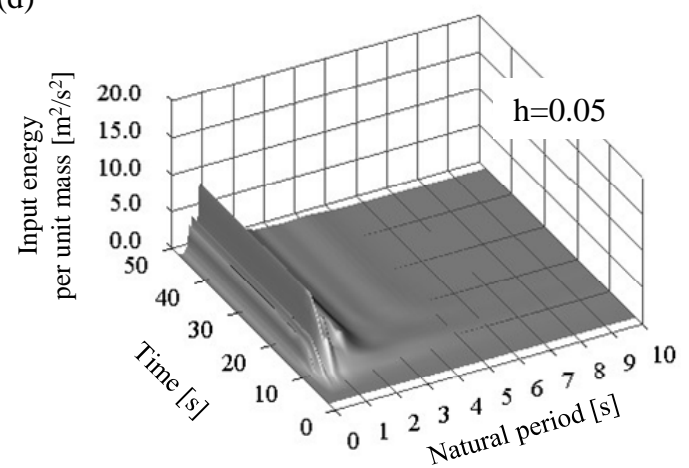

Fig.23 Time variation of input energy from ground motion at JMA Kobe (NS) during Hyogoken-Nanbu earthquake 1995 for various damping ratios 

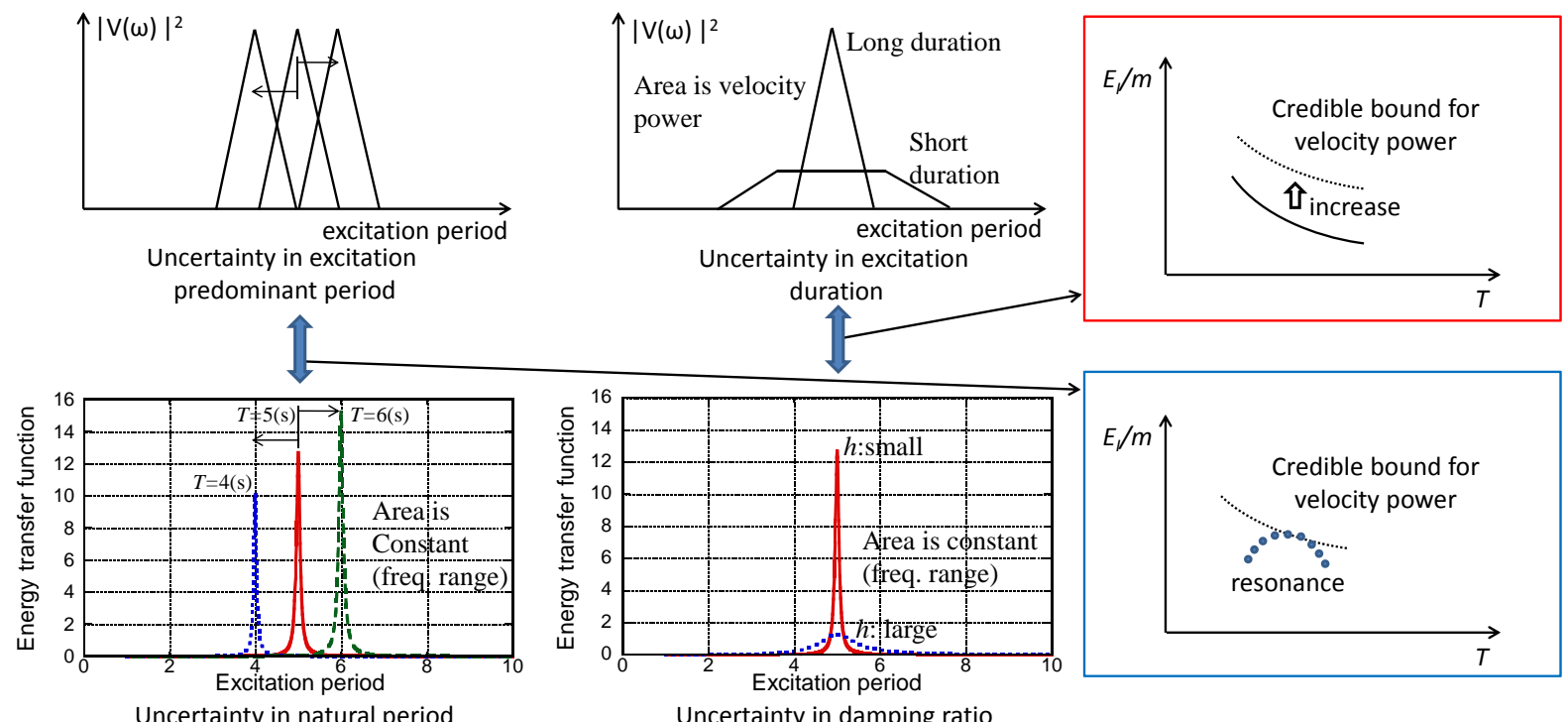

Fig.24 Increase of credible bound of input energy for velocity power constraint due to lengthening of input excitation duration and decrease of damping ratio of structure

Fig.24 shows the mechanism of increase of credible bound of input energy for the velocity power constraint due to uncertainties in input excitation duration (lengthening) and in structural damping ratio (decrease). As for uncertainties in excitation predominant period and in natural period of a structure, the resonant case is critical. It can be understood from Fig.6(c) and Fig.20 that the lengthening of input excitation duration and decrease of structural damping ratio may have caused large input in the super high-rise building in Osaka bay area. Especially the decrease of structural damping ratio induces unsmoothing of the energy spectrum and the period region to increase the energy spectrum happened to coincide with the fundamental natural period of the super high-rise building.

\section{Conclusions}

The following conclusions have been obtained.

(1) The 2011 off the Pacific coast of Tohoku earthquake is the most influential earthquake in Japan after the 1923 Great Kanto earthquake in terms of damaged area, number of victims and loss cost. This earthquake may be the world largest inter-plate earthquake which affected mega cities after the construction of super high-rise buildings. However this earthquake may not be the worst one. This fact has been confirmed by analyzing the response of high-rise buildings using a set of simulated ground motions provided by the Japanese Government and by predicting the ground motion intensity in comparison with that during the March, 11, 2011 earthquake [35].

(2) The ground motion recorded at the K-NET, Shinjuku station (TKY007), Tokyo contains fairly large long-period wave components (comparable to the level 1 for high-rise buildings in Japan) and has a frequency content of broad band (2-6 seconds). This can be observed from not only the velocity response spectra (and Fourier spectra) but also the earthquake input energy spectra taking into account of the concept of critical excitation. It was confirmed that the response simulation for assumed 60-story buildings without and with dampers under the ground motion at the K-NET, Shinjuku station correlates fairly well with the recorded one in the super high-rise building in Shinjuku. 
(3) The region of long natural period in the input energy spectrum can be controlled by the credible bound for the velocity constraint $[11,12]$. The introduction of the credible bound enables the construction of a reliable bound with uniform risk in longer natural period range influenced by long-period ground motions. This bound is expected to play a role for overcoming the difficulties caused by uncertainties on period and duration of long-period ground motions.

(4) The analysis of 'input energy rate' in the time-history context enables one to better understand characteristics of long-period ground motions and their effect on building responses. It has been made clear that the response of a super high-rise building in Tokyo and that in Osaka bay area exhibit a different characteristic, i.e. the existence of short-period wave components in the beginning of shaking. The role of damping in super high-rise buildings subjected to long-period ground motions can be well described by the input energy rate.

(5) Judging from Fig.24, the lengthening of input duration and decrease of damping ratio may be possibilities of large energy input, in addition to the resonance of the building fundamental natural period with the ground fundamental natural period, in the super high-rise building in Osaka bay area during the 2011 off the Pacific coast of Tohoku earthquake.

(6) Visco-elastic dampers (high-hardness rubber dampers with high damping capacity) and viscous dampers (oil dampers) are able to damp the building vibration during long-period ground motions in an extremely shorter duration compared to the building without those dampers. It has been made clear that the safety is not the only target and the functionality together with the psychological aspects of residents has to be taken into consideration appropriately.

The word 'unexpected issue' or 'black swan' is often used in Japan after this great earthquake. It may be true that the return period of this class of earthquakes at the same place could be 500-1000 years and the use of this word may be acceptable to some extent from the viewpoint of the balance between the construction cost and the level of safety. However, the critical excitation method is expected to enhance in a rational way the safety level of building structures under uncertain circumstances by expecting the unexpected [23]

The concepts of redundancy, robustness [36, 37] and resilience [38, 39] and their relationship may be a key factor for designing building structures with greater earthquake resilience.

\section{Acknowledgments}

Part of the present work is supported by the Grant-in-Aid for Scientific Research of Japan Society for the Promotion of Science (No.20656086, 21360267, 24246095). This support is greatly appreciated. The use of ground motion records at K-NET, Building Research Institute of Japan, Taisei Co. and Nikken Sekkei Co. is also highly appreciated. The ground motions provided by PEER Center [40] are also appreciated.

\section{References}

[1] Architectural Institute of Japan (AIJ). Preliminary reconnaissance report on the 2011 Off the Pacific coast of Tohoku earthquake, April 6, 2011 (in Japanese).

[2] Architectural Institute of Japan (AIJ). Preliminary reconnaissance report of the 2011 Tohoku-Chiho Taiheiyo-Oki earthquake, July 2011 (in Japanese).

[3] USGS. Magnitude 9.0 - NEAR THE EAST COAST OF HONSHU, JAPAN. (Available from http://earthquake.usgs.gov/earthquakes/eqinthenews/2011/usc0001xgp/\#summary [Accessed on 
May 3, 2011]).

[4] Ministry of Land, Infrastructure, Transport and Tourism (MLIT). Code draft for the retrofit of existing high-rise buildings and design guideline for new high-rise buildings, December 21, 2010 (in Japanese) (Available from http://www.mlit.go.jp/ report/press/house05_hh_ 000218.html [Accessed on January 11, 2011]).

[5] Earthquake Spectra. The Mexico Earthquake of September 19, 1985, Vol.4, Issue 3.

[6] Heaton T, Hall J, Wald D, Halling M. Response of high-rise and base-isolated buildings to a hypothetical M 7.0 blind thrust earthquake, Science 1995; 267: 206-211.

[7] Kamae K, Kawabe H, Irikura K. Strong ground motion prediction for huge subduction earthquakes using a characterized source model and several simulation techniques, Proc. of the13th WCEE, Vancouver, 2004.

[8] Ariga T., Kanno Y, Takewaki I. Resonant behavior of base-isolated high-rise buildings under long-period ground motions. The Struct. Design of Tall and Special Buildings 2006; 15(3): 325-338.

[9] Tani T, Yoshitomi S, Tsuji M, Takewaki I. High-performance control of wind-induced vibration of high-rise building via innovative high-hardness rubber damper, The Structural Design of Tall and Special Buildings 2009; 18(7): 705-728.

[10] Drenick RF. Model-free design of aseismic structures. J. Engrg. Mech. Div., ASCE 1970; 96(EM4): 483-493.

[11] Takewaki I. Bound of earthquake input energy. J. Struct. Engrg., ASCE 2004; 130(9): 1289-1297.

[12] Takewaki I. Critical Excitation Methods in Earthquake Engineering, Elsevier, 2006.

[13] Takewaki I. Critical excitation methods for important structures, invited as a Semi-Plenary Speaker, EURODYN 2008, July 7-9, 2008, Southampton, England.

[14] NIED (National Research Institute for Earth Science and Disaster Prevention). 2011 Off the Pacific coast of Tohoku earthquake, Strong Ground Motion, Emergency meeting of Headquarters for Earthquake Research Promotion, March 13, 2011. (Available from http://www.k-net.bosai. go.jp/k-net/topics/TohokuTaiheiyo_20110311/nied_kyoshin2e.pdf, [Accessed on April 20, 2011]).

[15] Takewaki I, Murakami S, Fujita K, Yoshitomi S, Tsuji M. The 2011 off the Pacific coast of Tohoku earthquake and response of high-rise buildings under long-period ground motions, Soil Dyn. Earthq. Engrg. 2011; 31(11): 1511-1528.

[16] Hisada Y, Yamashita T, Murakami M, Kubo T, Shindo J, Aizawa K, Arata T. Seismic response and damage of high-rise buildings in Tokyo, Japan, during the Great East Japan earthquake, Proc. Int. Symp. on Engineering Lessons Learned from the 2011 Great East Japan Earthquake, March 1-4, 2012, Tokyo, Japan, pp1110-1119.

[17] Asahi newspaper. Evening edition of April 19, 2011 (in Japanese).

[18] Kasai K, Pu W, Wada A. Responses of controlled tall buildings in Tokyo subjected to the great east japan earthquake, Proc. Int. Symp. on Engineering Lessons Learned from the 2011 Great East Japan Earthquake, March 1-4, 2012, Tokyo, Japan, pp1099-1109.

[19] Asahi newspaper. March 12, Evening edition of April 19, 2011 (in Japanese).

[20] Okawa I, Kashima T, Koyama S, Iiba M, Celebi M. Summary of recorded building responses during the 2011 off the Pacific coast of Tohoku earthquake with some implications to design motions, Proc. Int. Symp. on Engineering Lessons Learned from the 2011 Great East Japan Earthquake, March 1-4, 2012, Tokyo, Japan, pp1049-1060.

[21] Geller RJ, Jackson DD, Kagan YY, Mulargia F. Earthquakes cannot be predicted. Science 1997; 275: 1616.

[22] Stein RS. Earthquake conversations. Scientific American 2003; 288(1): 72-79.

[23] Aster, R. Expecting the unexpected: black swans and seismology, Seismological Research Letters 
2012; 83(1): 5-6 [http://www.seismosoc.org/publications/SRL/SRL_83/srl_83-1_op.html].

[24] Takewaki I. Building Control with Passive Dampers: -Optimal Performance-based Design for Earthquakes-, John Wiley \& Sons Ltd. (Asia), 2009.

[25] Trifunac MD. Energy of strong motion at earthquake source. Soil Dyn. Earthq. Engrg. 2008; 28: 1-6.

[26] Boore DM. Stochastic simulation of high-frequency ground motions based on seismological models of the radiated spectra, Bulletin of the Seismological Society of America 1983; 73(6): 1865-1894.

[27] Yamane T, Nagahashi S. Amplitude characteristics of the acceleration record in the 2011 off the Pacific coast of Tohoku earthquake and the simulated earthquake ground motions based on $\omega^{2}$ model, Proc. of Lessons from the Great Tohoku Earthquake Disaster and Construction of New Country, Architectural Institute of Japan, March 1-2, 2012, pp183-186 (in Japanese).

[28] Housner GW. Behavior of structures during earthquakes. J. Engrg Mech. Div., ASCE 1959; 85(4): 109-129.

[29] Akiyama H. Earthquake Resistant Limit-State Design for Buildings. University of Tokyo Press, Tokyo, Japan, 1985.

[30] Ohi K, Takanashi K, Honma Y. Energy input rate spectra of earthquake ground motions, J. Struct. Constr. Eng., AIJ 1991; 420: 1-7 (in Japanese).

[31] Takewaki I. Probabilistic critical excitation method for earthquake energy input rate, J. Eng. Mech., ASCE 2006; 132(9): 990-1000.

[32] Page CH. Instantaneous power spectra, J. Applied Physics 1952; 23(1): 103-106.

[33] Yamamoto K, Fujita K, Takewaki I. Instantaneous earthquake input energy and sensitivity in base-isolated building, The Structural Design of Tall and Special Buildings 2011; 20(6): 631-648.

[34] Kuwamura H, Kirino Y, Akiyama H. Prediction of earthquake energy input from smoothed fourier amplitude spectrum, Earthq. Eng. Struct. Dyn. 1994; 23(10): 1125-1137.

[35] Asahi newspaper. Evening edition of May 31, 2012 (in Japanese).

[36] Takewaki I. Robustness of base-isolated high-rise buildings under code-specified ground motions, The Structural Design of Tall and Special Buildings 2008; 17(2): 257-271.

[37] Architectural Institute of Japan (AIJ). Structural design with higher robustness and redundancy, $J$. Architecture and Building Science 2011; 126(1624): $73-79$ (in Japanese).

[38] Committee on National Earthquake Resilience Research, Implementation, and Outreach. Committee on Seismology and Geodynamics, National Research Council, National Earthquake Resilience: Research, Implementation, and Outreach, The National Academy’s Press, 2011.

[39] Takewaki I, Moustafa A, Fujita K., Improving the Earthquake Resilience of Buildings: The worst case approach, Springer (London), 2012

[40] Abrahamson N, Ashford S, Elgamal A, Kramer S, Seible F, Somerville P. Proc. of 1st PEER Workshop on Characterization of Special Source Effects, 1998. 